Report on the Hythe Crania

Author(s): F. G. Parsons

Source: The Journal of the Royal Anthropological Institute of Great Britain and Ireland, Vol. 38

(Jul. - Dec., 1908), pp. 419-450

Published by: Royal Anthropological Institute of Great Britain and Ireland

Stable URL: http://www.jstor.org/stable/2843308

Accessed: 07-12-2015 13:45 UTC

Your use of the JSTOR archive indicates your acceptance of the Terms \& Conditions of Use, available at http://www.jstor.org/page/ info/about/policies/terms.jsp

JSTOR is a not-for-profit service that helps scholars, researchers, and students discover, use, and build upon a wide range of content in a trusted digital archive. We use information technology and tools to increase productivity and facilitate new forms of scholarship. For more information about JSTOR, please contact support@jstor.org. 


\section{REPORT ON THE HYTHE CRANIA.}

By F. G. Parsons,

Lecturer on Anatomy at St. Thomas's Hospital and the London School of Medicine for Women.

[With Plate XXXV.]

THE large collection of bones beneath the church of St. Leonard at Hythe has given rise to a great deal of speculation and assertion as to its origin, but, with the exception of 100 measurements made by Dr. Randall Davis in 1899, no systematic series of measurements has ever been taken.

The present contribution is a series of measurements of 590 crania from Hythe, and, incidentally, of skulls measured by the author at Dover and Upchurch in Kent, for comparison. It is hoped that, at a later date, the results of the detailed examination of the face as well as of the rest of the skeleton may be submitted to this Institute.

\section{History of the Bones.}

It is quite certain that the bones have been in their present position for over two hundred years, because the Vicar of Cheriton, near Hythe (1679 to 1719), writing in 1700, says that all records of their origin had then been lost, and the townsmen could not account for them in any way. It will be an extremely. moderate computation to allow 79 years before 1679, when this vicar must have known of their existence, for all local tradition to have died out, so that we may safely say that the bones must have been under the church in 1600 and were probably placed there earlier.

In 1545 Leland visited Hythe and described the church somewhat inaccurately. He says that beneath it there is a "faire vault," but makes no mention of the bones.

This I think is all the real historical evidence available at present. Many battle theories have been advanced by Hasted and others to account for this, as they are so often advanced to account for other large collections of bones, but they have all been made comparatively recently, and have not stood the test of historical research.

Some medical observers have substantiated the battle theory by saying that the collection contains practically nothing but male bones which bear numerous marks of spear and battle axe wounds, and that, in addition, two perfectly distinct races are to be made out. How little this agrees with my own observation will be seen later on. I do not think it fair to take these gentlemen's opinions too seriously. Most of them are dead now, and any conclusions they formed were 
apparently the outcome of one or two flying visits of inspection, and were never intended as authoritative pronouncements. ${ }^{1}$

The opinion of Barnard Davis, however, is on quite a different footing. He, apparently, never saw the Hythe series, but obtained six of the skulls for his own collection which is now in the Museum of the Royal College of Surgeons. ${ }^{2}$ These, he said, by their shortness reminded him of the skulls of modern Germans, though he doubted whether they were other than those of Kentish people, whose only great battle had been that with death.

There seems every reasonable probability that these bones have been dug up from the churchyard and stacked under the church in the way which was quite usual in pre-Reformation days. It was then quite common, especially in towns, to have an ossuary beneath a church or a charnel house in close relation to it. There is said to be a large collection of bones walled up in the neighbouring church at Folkestone, while at Dover I had the opportunity in 1905 of inspecting and measuring some of a large series beneath the site of the vanished church of St. Peter, and these had been absolutely walled in and buried since the sixteenth century. At Upchurch, too, in the north of Kent, there is a small collection in a true crypt, and here also there is a battle tradition, though without any historic value.

The fact that Leland makes no mention of the bones does not, to my mind, prove that they were not there in 1545 , because, given a crypt, its proper furniture in those days would have been bones, and their presence need not have called for special comment. ${ }^{3}$

One point which is noticeable about the Hythe bones is the way they are, and apparently always have been, stacked in a long pile allowing a free passage way beside them. It is only lately that it has been appreciated that what is called the crypt in this church is really a processional way provided when the new choir was built in the reign. of King John. Since the time of the Reformation it has not been used for this purpose, and its north door has not only been closed but, until quite recently, has been earthed up on the outside by the gradual accumulation of soil.

It seems to me, and in this I have the full concurrence of the vicar, that the careful stacking of the bones along one side only of the processional way, and that the west side, and the free passage left close to the easternmost wall of the church, points to the bones having been placed where they are now while the processional was still used for the annual procession round the church, that is to say, in preReformation days, though how much earlier we cannot tell.

The date of the stacking of these bones is of some little importance. Both Dr. Knox and Mr. Frank Buckland state on hearsay evidence that the bones were

${ }_{1}$ Lest I should seem to wish to suppress evidence pointing to a conclusion at variance with my own, I would strongly advise anyone interested in these bones to read the two papers of Dr. Robert Knox, Proc. Ethnological Society, 1861 and 1863, as well as that of Frank Buckland in Curiosities of Natural History, 4th Series, p. 181.

2. In this series is, I believe, the very large skull described by G. Borrow in his novel Lavengro in 1851. He saw it in his boyhood, in the early years of the nineteenth century. By the courtesy of the Council a cast of this skull has been presented to the Hythe Collection.

${ }^{3}$ See also footnote on p. 422. 
stacked about the middle of the last century, and that before that time they were lying scattered about the floor. Against this is the evidence of the late Reverend James Browne, vicar of Cheriton and chaplain of the Cinque Ports, who mentions the pile of bones in 1700. In addition to this there is at present in the church at Hythe an old steel engraving dated 1783 and showing the stack as it is now. It is very probable that, at the time the skulls were placed upon the shelves in 1851, a few scattered bones which were on the floor, and possibly were recent additions, were cleared up and the stack made more complete. There is, however, no reason to believe that the main pile of bones differs in its position to-day from that it held when it was first erected.

Assuming, however, that the bones came into their present position somewhere about 1550 , and it is extremely unlikely' that they were much later, what reason have we for believing that they came from the adjoining churchyard?

In the first place I should point to the extreme probability of such a thing in the absence of any definite evidence to the contrary. That a large number of these bones have been buried is indicated by the presence of earth in the interior of the skull as well as in the orbits and auditory passages, while on some of them particles of woody fibre remain mixed with a few hairs adhering to the occipital region, pointing to the probability of their having been buried in coffins. Moreover, I have very little doubt that the so-called spear and battle axe wounds are really the work of spades and pickaxes, and were certainly inflicted when the skulls had become friable many years after death.

I have demonstrated the great difference produced by blows of the same force and with the same weapon on skulls of people recently dead and on those which had been buried many years and, from the experience thus gained, I feel sure that the injuries found in the majority of these skulls were not the injuries from which their owners died.

Then this great pile of bones represents the remains of at least 4,000 people, men, women and children. This is no mere rough estimate, but the result of counting all the heads of thighbones seen in restacking the whole pile which the vicar has lately had done. It is absurd to think that this number of people died at any one time in Hythe. The total population is at present little more than 5,000 , and although in the time of its greatest prosperity, which was in the reign of King John, the number of townspeople may have exceeded 4,000, there were at least four churchyards in which they could be buried. After this, until the time of Elizabeth, the town gradually declined.

Since the time of Elizabeth the entries of burials are available and, judging from these, it is evident that an allowance of forty burials a year for the preceding two or three centuries would be extremely liberal.

No doubt plague accounted for the death of some of these people, though certainly they did not all succumb in one visitation. We can study the effects of plague in the church records, and although the deaths are greatly increased in the particular plague years, they are correspondingly diminished for the succeeding three or four, 
so that the average of five or six years, including a plague year, does not appreciably differ from that of five or six in which no plague occurred.

One more point of historical interest must be mentioned and that is that the grave-yard formerly did not exceed about two-thirds of an acre, though in more modern times it has been twice enlarged. This possibly furnishes a clue to the presence of ossuaries beneath churches in pre-Reformation times, since the habit then seems to have been to use a small churchyard over and over again while in more modern times, as soon as one plot of land is filled, more is consecrated.

Taking all the above points into consideration it seems extremely probable in the absence of any reliable evidence to the contrary that this stack of bones was finished during the sixteenth century, and that the bones composing it were gradually dug up from this or some of the neighbouring Hythe churchyards during the sixteenth, fifteenth and possibly fourteenth centuries. That, as the people whose bones these were must have died at least fifty years before they were dug up, and would represent the total burials of more than a century, it is probable that we are dealing with the remains of Kentish people most of whom lived in the fourteenth and fifteenth centuries.

\section{General Examination of the Bones.}

Although it is my hope to furnish detailed results of the examination of series of different parts of the skeleton later on, it may not be out of place to say here that the 590 skulls which have been measured consist of those which were picked out of the stack in 1851 and placed upon shelves, where they are now shown.

In restacking the main pile of bones during the last few weeks, nearly as many measurable skulls again have been found and put aside, but there is no reason to think that those measured are not quite representative. It was evident from the débris that women's and children's skulls had, owing to their more fragile nature, suffered more seriously than those of men, and this fact, no doubt, accounts largely for the excess of male over female skulls on the shelves, which I have measured. Indeed, in most recorded collections of skulls the males exceed the females.

Three additional skulls were dug up a few years ago on the site of the church of St. Nicholas. This was one of the three, or perhaps four, small churches which were in Hythe during the thirteenth and part of the fourteenth centuries, but fell into decay with the decline of the town, and were no longer used in the fifteenth century. Leland in $1545 \mathrm{saw}^{1}$ the ruins of these churches. These three skulls are therefore interesting for comparison, since they cannot have been buried later than 1365, as there is good evidence that after this Hythe had only one church, that of St. Leonard, left.

Of the stature and physique of the mediæval Hythe people I hope to be able to speak with more detailed knowledge later, but a preliminary measurement of 155 femurs points to the men having averaged about 5 feet $5 \frac{1}{3}$ inches, while the

1 Or says that he saw them. Leland's account of Hythe and the adjacent church of Lympne makes me suspicious that he got his information from some neighbouring ecclesiastical centre, such as Canterbury or Saltwood, and never really visited the place. 
women were about 5 feet 1 inch. (The average length of 76 o femurs was $45 \cdot 1$ $\mathrm{cm}$. and of 79 \& femurs $41.8 \mathrm{~cm}$.)

There is no doubt that these people lived on coarse, rough food, since their teeth are in almost every case worn, often quite flat, and this applies to young people as well as old. At the same time caries is not nearly so common as it is in modern English people.

I regard this condition of the teeth as an indication that these people lived before bread was an ordinary article of diet, and when cakes of roughly ground meal were the ordinary fare. At any rate, the state of these teeth was identical with that of those found under St. Peter's at Dover, which almost certainly came from people who lived in the thirteenth and fourteenth centuries. They also form a contrast with the skulls I have examined from a disused churchyard under the site of the Bluecoat School near Newgate, most of which were from seventeenth century Londoners, and in which, while the wearing down was much less marked, caries was more common. In the recent restacking of the pile, several masses of hair were found, in which shades of red predominate. It is, I believe, a recognized fact that black and brown hair turns red by keeping, but in addition there is a good deal of flaxen hair, some of which, evidently from children, is done up in plaits. I fear, however, that the amount is quite insufficient to give us any good idea of the predominant hair tints of these people.

Besides the hair, a quantity of coarse earthenware pottery and wooden platters was found in the pile, as well as the upper part of an old shoe or boot of a very different cut from the present. All these things will be submitted to experts and reports furnished in due course. ${ }^{1}$

It should perhaps be mentioned besides that in the vault are some thirteenth and fourteenth century stone crosses, formerly gravestones, as well as part of the lid of a fourteenth century stone coffin. These, of course, need not necessarily have been connected with the bones, though they give some indirect evidence that burials of those times were later on disturbed.

\section{Pathological Observations.}

A large number of pathological specimens have come to light, many of which I have submitted to Mr. S. G. Shattock, who has been kind enough to advise me upon them. The commonest trouble undoubtedly is osteo-arthritis, from which a great many of these people must have suffered terribly.

Ten or twelve examples of syphilitic lesions were found in the form of ulcerations, necroses, gummata and periostitis. One skull with a large gummatous heaping up of bone has been shown to countless visitors in the past as an instance of a healing wound. If the modern theory that syphilis was brought from America by Columbus be true, these specimens were probably some of the later additions to the pile.

1 Since the above was written the pottery has been taken to the Medieval Department of British Museum, and there pronounced to be characteristic of the fourteenth and fifteenth centuries. The wooden platters closely resemble those preserved in the old Leper's Hospital at Harbledown near Canterbury. 
Evidences of ante-mortem injury are numerous, several fractured tibiæ and one or two fractured femora were found, and it is wonderful what good, straight unions were made. There are also several instances of healing wounds of the skull quite distinct from the much more numerous spade and pick-axe injuries already discussed.

The frequency of injuries quite bears out the reputation for turbulence which the Cinque Ports enjoyed during the middle ages.

I have seen the rickety tibia noticed by Dr. Knox, but apart from that have come across no evidence of the disease which I could recognize.

\section{Measurements of the Crania.}

I have divided the 590 skulls into 326 males over 20,230 females over 20 , and 34 children of both sexes up to 20 ; that is to say, until the suture between the basi-occipital and basisphenoid bones closes.

The division into males and females is, of course, only done to the best of my ability, and is liable to revision. Still, I have given great care to this point, and have placed a mark of interrogation against those skulls in the list which have given me most trouble in determining the sex.

I do not feel justified in giving an approximate age to the possessors of the skulls until I have the skull cap removed and cleaned, since my experience teaches me that the most reliable evidence is the amount of internal closure of the sutures. (See "Relation of the Cranial Sutures to Age," by F. G. Parsons and C. R. Box, Journ. Anthrop. Inst., vol. xxxv, 1905, p. 30.) From what I can see, however, I should say that 242 are from people over 40 , and 275 between 20 and 40 years.

This I should think a probably fair estimate when one remembers the numerous visitations of plague in the fourteenth and fifteenth centuries, and the notorious turbulence of the Cinque Port inhabitants.

Apart from the personal element which must always be discounted, I did not expect to find the female and children's skulls in anything like their due proportion on these shelves. It must be remembered that these bones have probably gone through the sorting processes of (1) decay in the damp ground; (2) exhumation; (3) stacking and its pressure effects; (4) modern handling. There are enormous numbers of fragmentary skulls in the great pile, and in these the women and children doubtless are in excess of the men. The inclusion of a certain number of female skulls among the males is probably counter-balanced to a certain extent by the reverse process, though in my case I do not think to the same amount. In any case, as long as the sexing of skulls remains a question of individual judgment, nothing approaching mathematical accuracy can be expected from the results of measurements, though I find that by shifting a block of 100 more or less doubtful skulls from one sex to the other, I have only succeeded in altering the average length index by $\cdot 1$ per cent.

The measurements I have taken are :-

1. The ophryo-maximal length.

2. The glabello-maximal length. 
3. The greatest parietal breadth.

4. The least frontal breadth taken where the temporal ridges come closest together.

5. The basi-bregmatic height.

6. The auricular height.

Personally, I prefer to work with the ophryo-maximal length rather than with the glabello-maximal, because it is uninfluenced by the size of the frontal sinuses, and also because it is more often available. Still, I think the two measurements should always be taken; partly for comparison with Continental measurements, and also because the contrast between the two lengths gives a clue to the development of the frontal sinuses, on the one hand, or the bulging forward of the forehead as it ascends, on the other.

I have also included the usual breadth and height indices, calculated by using the ophryo-maximal length as a standard in each case.

I confess that these indices mean little to me. If I am given the length, breadth, and height of a skull, I can roughly picture it and compare it with the average measurements of known series, but a skull with a high breadth index may be one of normal length and great breadth, or of normal breadth and little length.

TABLE I.-Length.

\begin{tabular}{|c|c|c|c|c|c|c|c|c|}
\hline \multirow{3}{*}{ 一 } & \multicolumn{4}{|c|}{ Males. } & \multicolumn{4}{|c|}{ Females. } \\
\hline & \multicolumn{2}{|c|}{ Ophryo-maximal. } & \multicolumn{2}{|c|}{ Glabello-maximal. } & \multicolumn{2}{|c|}{ Ophryo-maximal. } & \multicolumn{2}{|c|}{ Glabello-maximal } \\
\hline & No. & Length. & No. & Length. & No. & Length. & No. & Length. \\
\hline Hythe & 324 & $\begin{array}{l}\mathrm{cm} . \\
17 \cdot 7\end{array}$ & 319 & $\begin{array}{l}\mathrm{cm} . \\
17 \cdot 9\end{array}$ & 230 & $\begin{array}{l}\mathrm{cm} . \\
17 \cdot 1\end{array}$ & 227 & $\begin{array}{l}\mathrm{cm} . \\
17 \cdot 1\end{array}$ \\
\hline Whitechapel & 138 & $18 \cdot 7$ & 137 & $18 \cdot 9$ & 143 & $18 \cdot 0$ & 140 & $18 \cdot 0$ \\
\hline Moorfields ... ... & 45 & $18 \cdot 7$ & 44 & $18 \cdot 9$ & 65 & $18 \cdot 2$ & 63 & $18 \cdot 3$ \\
\hline Christ's Hospital .. & 61 & $18 \cdot 3$ & - & - & - & - & - & - \\
\hline Cambridge Under & & & & & & & & \\
\hline $\begin{array}{l}\text { graduates } \\
\text { St. Thomas's Hos- }\end{array}$ & - & - & 1,000 & $18 \cdot 2$ & - & - & - & - \\
\hline pital Students & 97 & $18 \cdot 1$ & - & - & - & - & - & - \\
\hline $\begin{array}{l}\text { Women's Medical } \\
\text { School Students. }\end{array}$ & & & & & & & & \\
\hline $\begin{array}{l}\text { School Students.. } \\
\text { Bedford College }\end{array}$ & - & - & - & - & 50 & $17 \cdot 5$ & - & - \\
\hline Students... & - & - & - & - & - & - & small series & $17 \cdot 9$ \\
\hline British Association & - & - & $?$ & $18 \cdot 7$ & - & - & $?$ & $17 \cdot 5$ \\
\hline English criminals .. & - & - & 3,000 & $18 \cdot 1$ & - & - & - & - \\
\hline Upchurch ... .. & 16 & $18 \cdot 2$ & - & - & 5 & $17 \cdot 8$ & - & - \\
\hline Dover $\quad \ldots$ & 12 & $18 \cdot 3$ & - & - & - & - & - & - \\
\hline Bavarian $\ldots$ & - & - & 100 & $18 \cdot 1$ & - & - & 100 & $17 \cdot 3$ \\
\hline Würtemberg & - & - & 97 & $17 \cdot 9$ & - & - & 19 & $17 \cdot 3$ \\
\hline French soldiers & - & - & 56 & $18 \cdot 0$ & - & - & - & - \\
\hline Long Barrow & 17 & $18 \cdot 7$ & 16 & $19 \cdot 1$ & 12 & $1 \cdot 84$ & 13 & $18 \cdot 3$ \\
\hline
\end{tabular}

On looking at the above table the shortness of the Hythe skulls is very striking; they are shorter than anything else in the table except the glabellomaximal length of the Würtemberg males, while the female length of $17 \cdot 1$ is less even than that of the German female skulls. 
Judging from the Hythe, Whitechapel and Moorfield series, which, taken together, include 507 male and 438 female skulls, it seems that the male English skull averages about two $\mathrm{mm}$. more in the glabello-maximal than it does in the ophryo-maximal length, while in the female skulls the two lengths are practically the same.

In this and the following tables the Whitechapel and Moorfields skulls are those published by Dr. Macdonell in Biometrika, vol. iii, 1904, and vol. v, 1906.

The Christ's Hospital series was one I measured myself, and was dug up close to the site of the old Blue Coat School. It was in a disused grave-yard, and, among other remains, contained those of many prisoners who died in Newgate. From the way the bodies were buried I have little doubt that part at least of it had been used as a plague pit during the great plague.
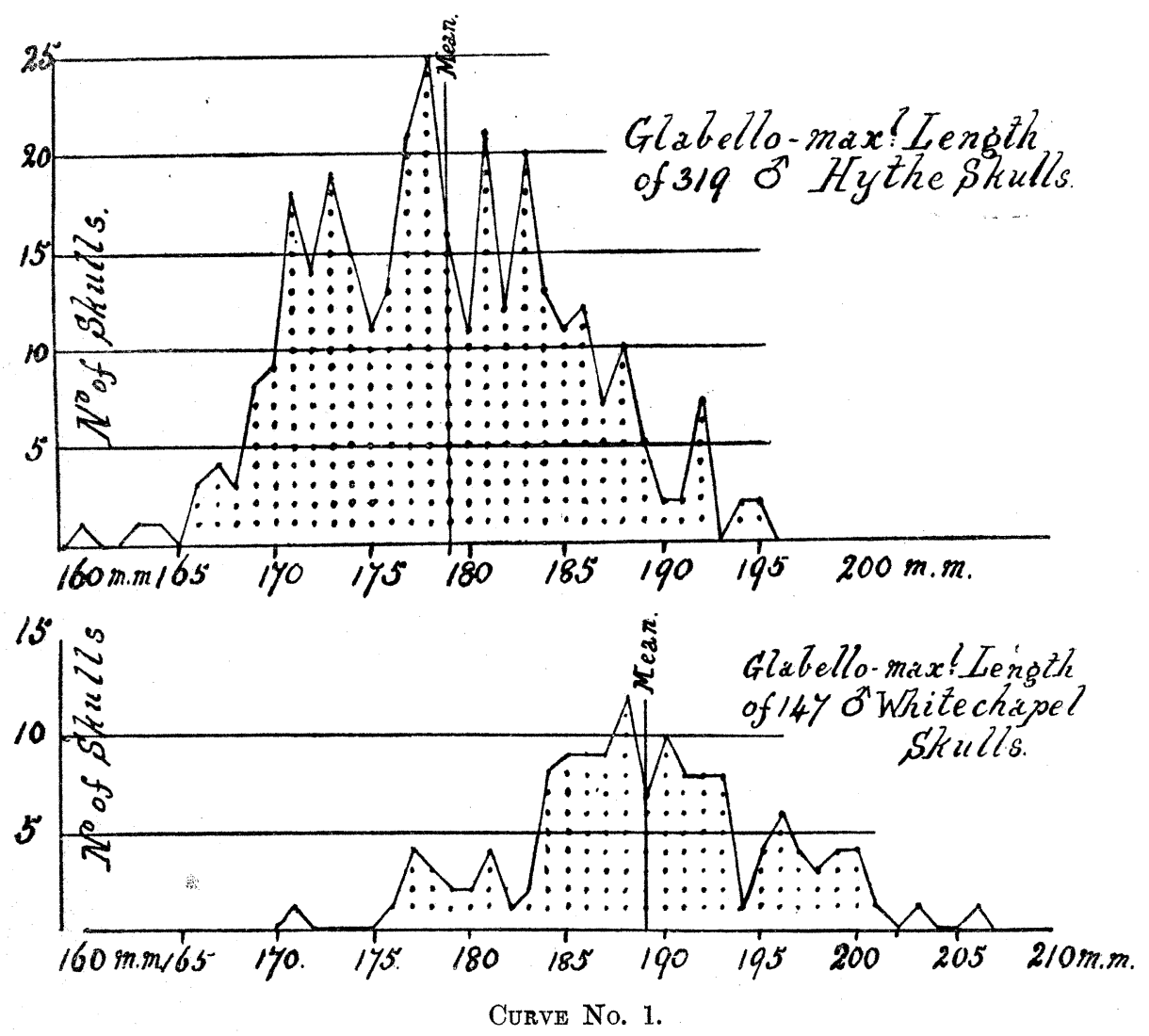

The St. Thomas's Hospital and Women's School measurements were made by me in 1907-08 on my own students in these medical schools, and the figures were gained by subtracting $11 \mathrm{~mm}$. from the living measurements.

The Dover skulls were part of a large collection removed from the site of St. Peter's Church in Dover during some recent excavations. For the chance of seeing these I am indebted to the kindness of Canon Bartram. They are probably 
about the same date as the Hythe skulls, but, owing to the crypt having been filled in with moist earth, very few were available for measurement.

The Upchurch skulls are in the crypt of the church there, not far from Rochester, and here again I am indebted to the kindness of the vicar. Indeed I should like to take this opportunity of acknowledging the unfailing kindness and help I have received from the many clergymen I have come across in the course of my various investigations. To the Reverend $H$. Dale of Hythe and the vicars of Christ Church and St. Sepulchre's in the City, I am especially indebted. I have been surprised and delighted at the extent of these gentlemen's knowledge of the unwritten history of their parishes, and only regret that space does not allow me to set down all I have learnt from them.
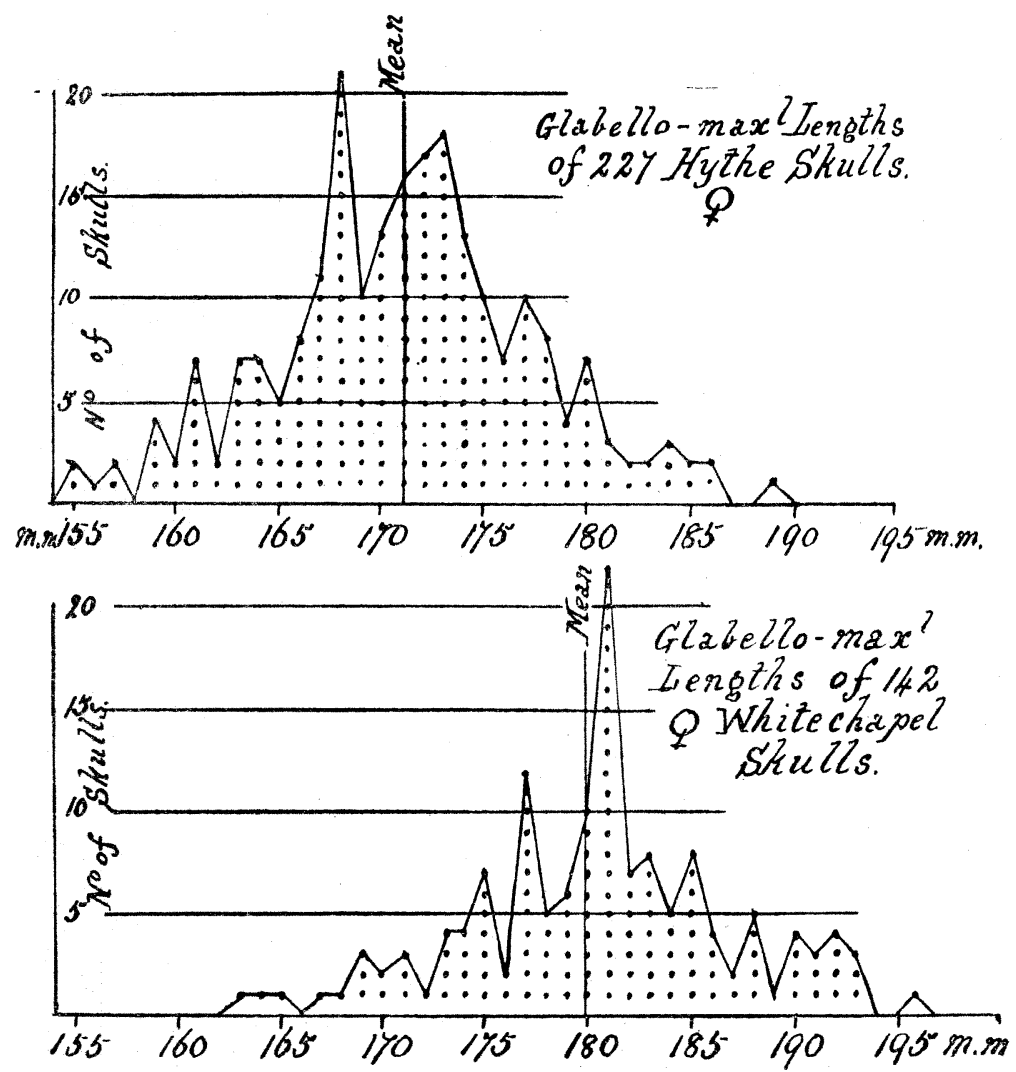

Curve No. 2.

The other series of skulls in the tables are taken from Dr. Macdonell's great works on the Whitechapel and Moorfields skulls already quoted. I have, however, taken the liberty of reducing the measurements to the nearest millimetre, since I feel that, so long as the determination of sex remains so uncertain, little is gained by working them out to several places of decimals. Indeed my absence of mathematical training would have made this very laborious in my own series.

The accompanying curves ( 1 and 2 ), contrasting the grouping of these skull lengths in the Hythe and Whitechapel series show that the Hythe skulls are in every 
way as homogeneous a series as are those from Whitechapel, and that in neither group is there any appreciable mixture of types. The contrast between these two groups is worth making because, as far as we know, they represent the extremes of English skull lengths as demonstrated by large and homogeneous collections. It seems to me possible that Dr. Macdonell tends to err on the side of making too many doubtful skulls female, while my own tendency to error is in the opposite direction, but it is extremely unlikely that, if each of us determined the sexes of the other's collection, independently and anew, the means would approach one another by more than $1 \mathrm{~mm}$.

Table 2.-Breadth.

\begin{tabular}{|c|c|c|c|c|c|c|c|c|}
\hline \multirow{3}{*}{ - } & \multicolumn{4}{|c|}{ Males. } & \multicolumn{4}{|c|}{ Females. } \\
\hline & \multicolumn{2}{|c|}{ Greatest parietal. } & \multicolumn{2}{|c|}{ Least frontal. } & \multicolumn{2}{|c|}{ Greatest parietal. } & \multicolumn{2}{|c|}{ Least frontal. } \\
\hline & No. & Breadth. & No. & Breadth. & No. & Breadth. & No. & Breadth. \\
\hline Hvthe & 324 & $\mathrm{~cm}$. & 318 & $\mathrm{~cm}$. & 930 & $\mathrm{~cm}$. & (988 & $\mathrm{cm}$. \\
\hline Whitechapel & 135 & $14 \cdot 1$ & 132 & $9 \cdot 8$ & 140 & 13.5 & 147 & $9 \cdot 3$ \\
\hline Moorfields ... $\ldots$ & 46 & $14 \cdot 3$ & 47 & $9 \cdot 85$ & 62 & $13 \cdot 8$ & 64 & $9 \cdot 5$ \\
\hline Christ's Hospital ... & 61 & $13 \cdot 9$ & - & - & 23 & $13 \cdot 4$ & - & - \\
\hline $\begin{array}{c}\text { Cambridge Under- } \\
\text { graduates }\end{array}$ & 1000 & $14 \cdot 3$ & - & - & - & 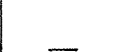 & & \\
\hline 'St. Thomas's Hos- & & & & & & & & - \\
\hline $\begin{array}{l}\text { pital Students ... } \\
\text { 'Women's Medical }\end{array}$ & 97 & $14 \cdot 1$ & 92 & $9 \cdot 8$ & - & - & - & - \\
\hline $\begin{array}{l}\text { School Students } \\
\text { Bedford College }\end{array}$ & - & - & - & - & 50 & $13 \cdot 7$ & 50 & $9 \cdot 7$ \\
\hline $\begin{array}{c}\text { Bedford College } \\
\text { Students... }\end{array}$ & - & - & - & - & small serres & $13 \cdot 6$ & - & - \\
\hline British Association & $?$ & $14 \cdot 4$ & - & - & $?$ & $13 \cdot 7$ & - & - \\
\hline English criminals ... & 3,000 & $13 \cdot 9$ & - & - & - & - & - & - \\
\hline Upchurch ... & 16 & $14 \cdot 4$ & - & - & 5 & $13 \cdot 5$ & - & - \\
\hline Dover $\quad \ldots$ & 12 & $14 \cdot 3$ & - & - & - & - & - & - \\
\hline Bavarian ... & 100 & $15 \cdot 0$ & 72 & $10 \cdot 4$ & 100 & $14 \cdot 4$ & 83 & $9 \cdot 6$ \\
\hline Würtemberg & 96 & $14 \cdot 8$ & 98 & $9 \cdot 7$ & 19 & $14: 3$ & 19 & $9 \cdot 4$ \\
\hline French soldiers & 56 & $14: 3$ & 56 & $9 \cdot 6$ & - & - & - & - \\
\hline Long Barrow & 18 & $14 \cdot 2$ & 16 & $9 \cdot 9$ & 12 & $13 \cdot 9$ & 11 & $9 \cdot 4$ \\
\hline
\end{tabular}

It will be seen from this table that the parietal and frontal breadths of the Hythe skulls are well developed, but not exceptionally so, while the accompanying curve shows the homogeneous nature of the group and the range of variation. (Curve 3.)

Table 3 shows that the Hythe skulls are of considerable height, indeed, their basibregmatic height is only surpassed by the Bavarian and Long Barrow skulls. This applies both to the male and females. Their homogeneity and range of variation is shown in the accompanying curve. (Curve 4.)

The relation between the auricular and basibregmatic heights may, I think, prove a point of considerable classificatory importance as,our supply of material increases. In the male Hythe skulls the auricular height averages $13 \mathrm{~mm}$. less than the basibregmatic, while in the females it is only $12 \mathrm{~mm}$. less.

${ }^{1}$ In arriving at these measurements I deducted $11 \mathrm{~mm}$. in the parietal breadth, but experience in the Dissecting Room showed me that $6 \mathrm{~mm}$. was ample to deduct from the living frontal breadth. 
F. G. Parsons.-Report on the Hythe Cranic.
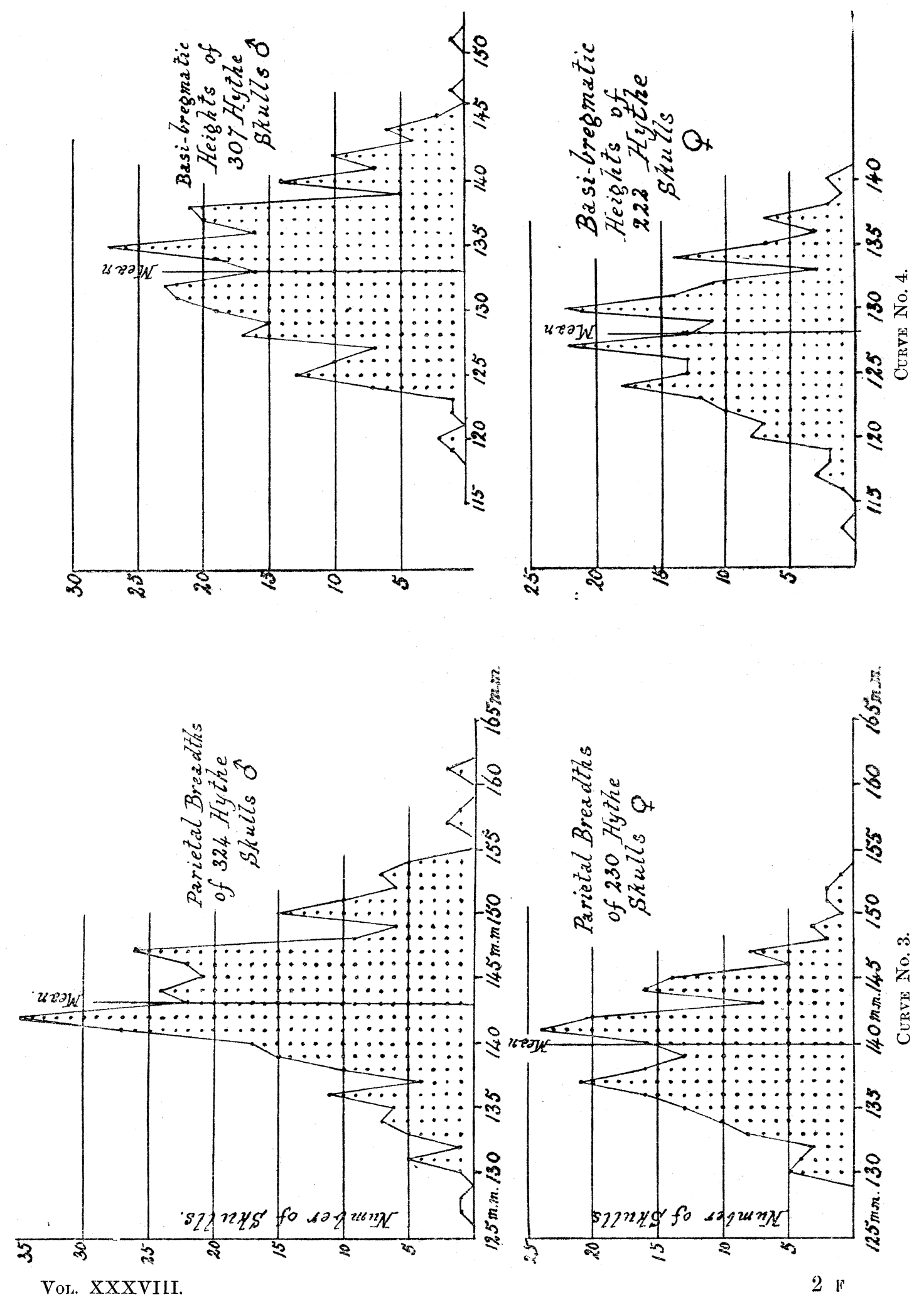
TABLE 3.-Height.

\begin{tabular}{|c|c|c|c|c|c|c|c|c|}
\hline \multirow{3}{*}{-} & \multicolumn{4}{|c|}{ Males. } & \multicolumn{4}{|c|}{ Females. } \\
\hline & \multicolumn{2}{|c|}{ Basi-bregmatic. } & \multicolumn{2}{|c|}{ A uricular. } & \multicolumn{2}{|c|}{ Basi-bregmatic. } & \multicolumn{2}{|c|}{ Auricular. } \\
\hline & No. & Height. & No. & Height. & No. & Height. & No. & Height. \\
\hline Hythe & 307 & $\begin{array}{l}\mathrm{cm} . \\
13 \cdot 3\end{array}$ & 294 & $\begin{array}{l}\mathrm{cm} . \\
12 \cdot 0\end{array}$ & 222 & $\begin{array}{l}\mathrm{cm} . \\
12 \cdot 8\end{array}$ & 215 & $\begin{array}{l}\mathrm{cm} . \\
11 \cdot 6\end{array}$ \\
\hline Whitechapel & 122 & $13 \cdot 2$ & 135 & $11 \cdot 5$ & 124 & $12 \cdot 5$ & 143 & 10.9 \\
\hline Moorfields ... $\ldots$ & 34 & $13 \cdot 0$ & 46 & $11 \cdot 4$ & 47 & $12 \cdot 4$ & 59 & $10 \cdot 9$ \\
\hline St. Thomas's Hos- & & & & & & & & \\
\hline $\begin{array}{l}\text { pital Students ... } \\
\text { Women's Medical }\end{array}$ & - & - & 53 & $12 \cdot 1$ & - & - & - & - \\
\hline School Students... & - & - & - & - & - & - & 25 & $11 \cdot 7$ \\
\hline Upchurch ... ... & 13 & $13 \cdot 2$ & - & -2 & \multirow{2}{*}{\multicolumn{2}{|c|}{$\begin{array}{l}\text { Very few skulls } \\
\text { available }\end{array}$}} & $\int-$ & - \\
\hline Dover $\quad \ldots$ & 12 & $13 \cdot 0$ & - & $-\}$ & & & $\{-$ & - \\
\hline Bavarian $\ldots$ & 99 & $13 \cdot 4$ & 100 & $12 \cdot 1$ & 96 & $12 \cdot 8$ & 100 & $11 \cdot 4$ \\
\hline Würtemberg & 93 & $13 \cdot 1$ & 94 & $11 \cdot 5$ & 19 & $12 \cdot 6$ & 19 & $11 \cdot 2$ \\
\hline French soldiers & 56 & $13 \cdot 1$ & 56 & $11 \cdot 3$ & - & - & - & - \\
\hline Long Barrow & 12 & $13 \cdot 8$ & 9 & $12 \cdot 1$ & 9 & $13 \check{\check{5}}$ & 3 & $11 \cdot 8$ \\
\hline
\end{tabular}

This, it will be noticed, is the same amount as is present in the male Bavarian skulls, but is lower than that of every other series put in the tables for comparison.

The accompanying curve shows the auricular and basi-bregmatic heights of fifty skulls taken at random from the male series, and indicates how very wide the range of variation is from the mean $13 \mathrm{~mm}$. (Curve 5.)

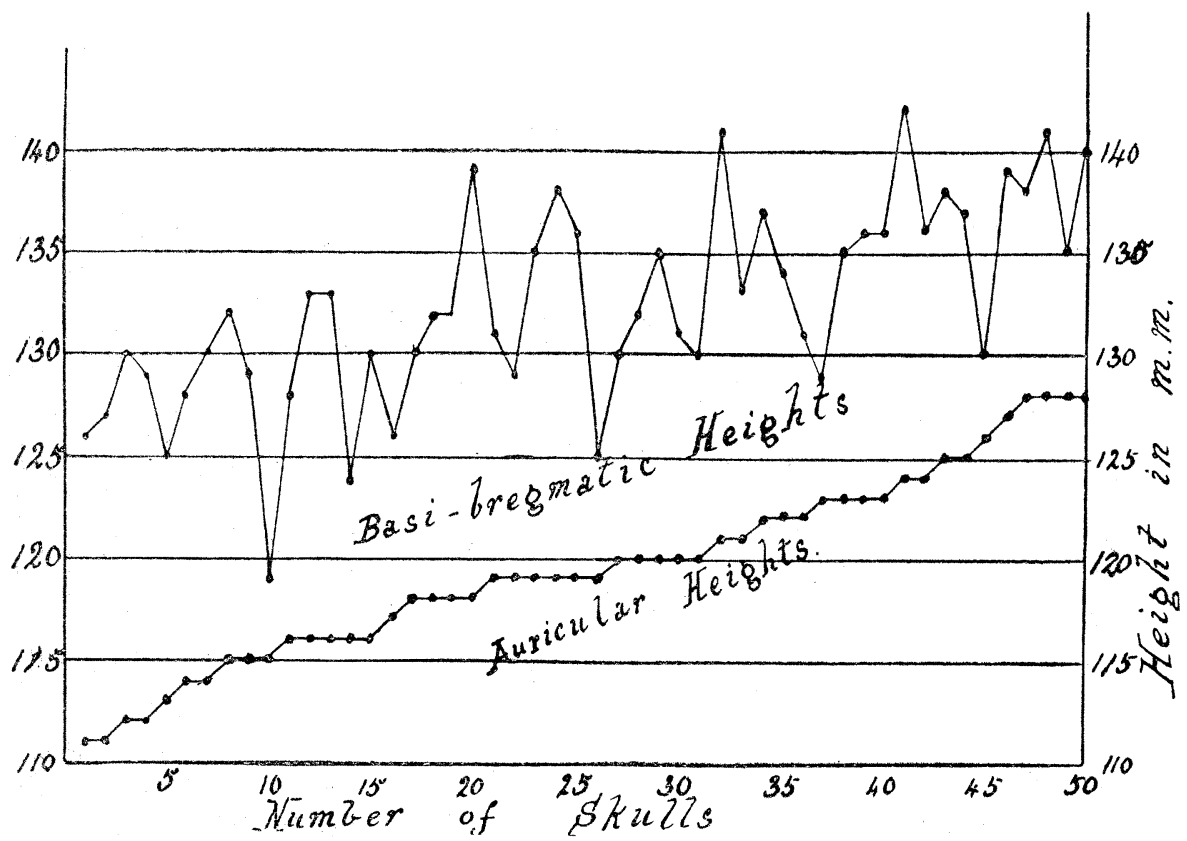

Curve No. 5. 
Sometimes there is only $4 \mathrm{~mm}$. difference between the two heights; at others as much as $21 \mathrm{~mm}$. Indeed, among the female skulls in the collection there are three in which the basi-bregmatic height is only $1 \mathrm{~mm}$. more than the auricular.

This variability would make the auricular height a most uncertain factor in estimating the actual height of skulls when a very small series is being dealt with, but when consecutive series of ten skulls are taken, the liability of variation is reduced to about $1 \mathrm{~mm}$. each way, while if series of twenty are dealt with, it for all practical purposes disappears.

\section{Indices.}

The breadth and height indices vary of course with the particular length which is chosen for comparison. It does not make very much difference whether the ophryo-maximal or glabello-maximal is used, but it may, and in the case of the male Hythe skulls does, make all the difference as to whether they fall into the brachycephalic or mesaticephalic classes. I have, therefore, in the following tables placed both calculations side by side wherever both lengths are available, since I do not know whether there is any authoritative decision as to which should be used in classifying skulls according to their indices.

TABLE 4.-INDICES.

\begin{tabular}{|c|c|c|c|c|c|c|c|c|c|c|c|c|c|}
\hline & & & & \multicolumn{5}{|c|}{ Males. } & \multicolumn{5}{|c|}{ Females. } \\
\hline & & & & \multicolumn{3}{|c|}{ Breadth. } & \multicolumn{2}{|c|}{ Height. } & \multicolumn{3}{|c|}{ Breadth. } & \multicolumn{2}{|c|}{ Height. } \\
\hline & & & & O.M.L & G.M.L. & F.r. & O.M.L. & G.M.L.L. & O.M.L. & G.M.L. & F.P. & O.M.L. & G.M.L. \\
\hline Hythe... ... & $\ldots$ & $\ldots$ & & 808 & 799 & 692 & 751 & 743 & 819 & 819 & 686 & 749 & 749 \\
\hline Whitechapel ... & $\ldots$ & $\ldots$ & & 754 & 743 & 695 & 706 & 698 & 750 & 750 & 689 & 694 & 694 \\
\hline Moorfields $\quad \ldots$ & $\ldots$ & $\ldots$ & . & 765 & 756 & 688 & 695 & 688 & 758 & 754 & 688 & 681 & 678 \\
\hline Christ's Hospital & & $\ldots$ & .. & 760 & - & - & - & - & - & - & - & - & - \\
\hline \multirow{2}{*}{\multicolumn{4}{|c|}{ Women's Medical Sehool Students }} & 779 & - & 695 & - & - & - & - & - & - & - \\
\hline & & & & - & - & - & - & - & 783 & - & 708 & - & - \\
\hline \multicolumn{4}{|c|}{ Bedford College Students $\ldots$} & - & - & - & - & - & - & 760 & - & - & - \\
\hline \multicolumn{4}{|c|}{ Cambridge Undergraduates } & - & 783 & - & - & - & - & - & - & - & - \\
\hline British Association & $\ldots$ & $\ldots$ & .. & - & 770 & - & - & - & - & 783 & - & - & - \\
\hline English criminals & $\ldots$ & $\ldots$ & .. & $\ldots$ & 772 & - & - & - & - & - & - & - & - \\
\hline Upchurch $\quad \ldots$ & $\ldots$ & $\ldots$ & .. & 791 & - & - & 725 & - & 758 & -- & - & - & - \\
\hline Dover... & $\ldots$ & $\ldots$ & .. & 781 & - & - & 710 & - & - & - & - & - & - \\
\hline Bavarian $\quad \ldots$ & $\ldots$ & $\ldots$ & .. & - & 832 & 693 & - & 740 & - & 832 & 666 & - & 740 \\
\hline Würtemberg ... & $\ldots$ & $\ldots$ & .. & - & 824 & 655 & - & 732 & - & 827 & 657 & - & 728 \\
\hline French soldiers & $\ldots$ & $\ldots$ & & - & 798 & 671 & - & 728 & - & - & - & - & - \\
\hline Long Barrow... & $\ldots$ & ... & & 759 & 743 & 697 & 738 & 723 & $75 \tilde{5}$ & 760 & 676 & 734 & 738 \\
\hline
\end{tabular}

Of the letters which head the columns, O.M.L. signifies an index taken with the ophryo-maximal length, G.M.L. one with the glabello-maximal, while F.P. is the fronto-parietal breadth index. The higher this index is the greater is the forehead breadth in comparison with that of the parietal region. In both the Hythe and Whitechapel series this index is six lower in the females than in the males, while in the Bavarian it is as much as twenty-seven lower. In the Women 
Medical Students it is very high, which is worth noting when it is remembered that these are women of more than average intellect and mental training.

\section{Capacity.}

I have only at present taken the capacity of eight skulls, four male and four female, for the purpose of testing the various methods of estimating the capacity from the measurements. ${ }^{1} \quad$ I find that Pearson and Lee's formula,

G.M. length $\times$ breadth $\times$ auricular height $\times \cdot 000337+406$ for male skulls, and

G.M. length $\times$ breadth $\times$ auricular height $\times \cdot 000400+206$

for females, gives the best results except in one-particular skull which was scaphocephalic. The results were much closer to the actual capacity, taken by shot, in the males than in the females.

Using Pearson and Lee's method on the average measurements of all the Hythe skulls already recorded, it would give the male skulls an average capacity of 1,441 c.c. and the females of 1,206 c.c. I fancy this is rather too low an estimate for the females, but in any case it is certain that these skulls are rather below the average of those of modern English people, just as the stature of their possessors was below that of modern middle-class Englishmen. I quite admit that more extended series of actual measurements of capacity are needed, but as things are it is very difficult to make them.

\section{Skull Shape.}

Every variety of skull shape may be found in the collection, but the most striking character is the number of skulls which have a steep, almost vertical, hinder end. The transition from the upper to the posterior surfaces is, therefore, comparatively sudden. The female skull (Plate XXXV, Figs. 1-3) gives a fair though not marked example of this. Bulging of the occipital bone is often coincident with this. The flattening of the posterior aspect, when it is very marked, gives the upper surface of the skull a sphenoid appearance, i.e., a quadrilateral with a narrow surface anteriorly and a broad one posteriorly.

\section{Comparison with St. Nicholas Skulls.}

Having considered the different measurements of the skulls found in the vault of St. Leonard's church, it will be possible to compare them with those of the skulls dug up a few years ago in making a new revolver range at the School of Musketry and on the site of the old church of St. Nicholas. There is really very little doubt that these skulls were buried during the first half of the fourteenth century or earlier, since after 1365 the church was no longer used.

Two of these skulls are female and one male; they are considerably more decayed than the others, but this is easily explained by their having been in the ground during the three and a half centuries in which the St. Leonard's bones have probably been in the vault.

1 The methods tried were those mentioned by Dr. Beddoe in his paper published in Journ. Anthrop. Inst., vol. xxxiv, p. 266. 
TABLE 5 .

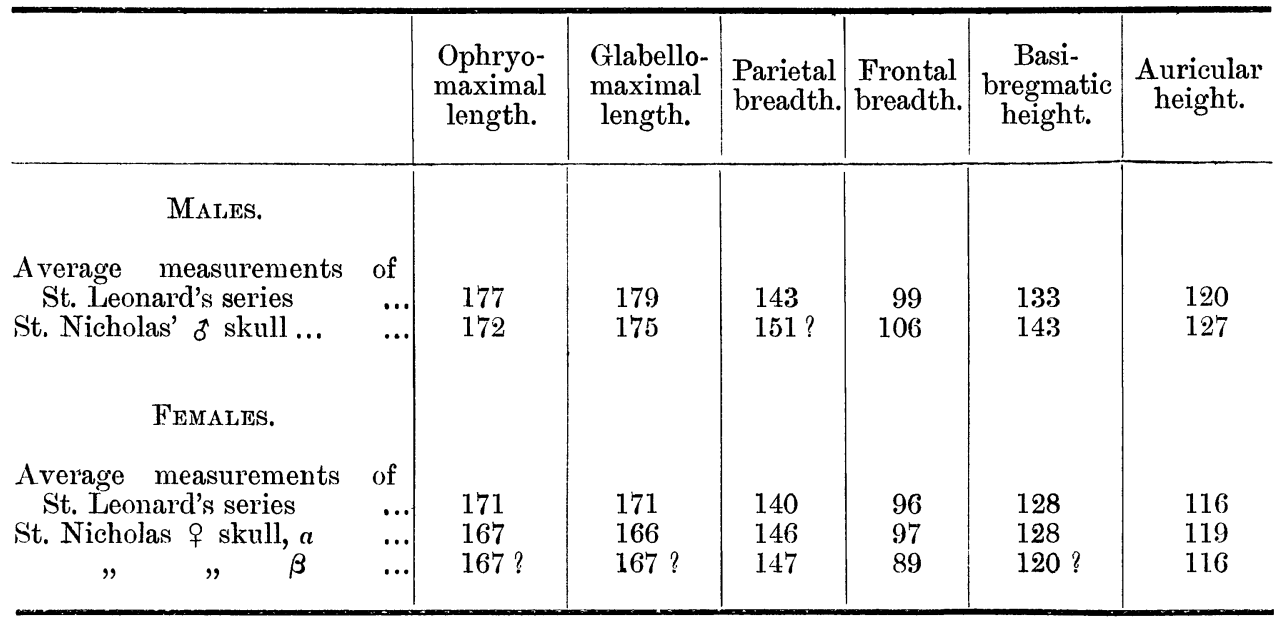

From the above it will be evident that the chief characteristic of the Hythe skulls, their shortness, is very marked in these.

\section{Variations in Sutures, Form, ETC.}

\section{Bathrocephaly.}

A marked bulging in the occipital region occurs in 51 of the 590 skulls, i.e., in 8.6 per cent. It is, relatively, more frequent in males than in females, and in nearly two-thirds of the cases in which it occurs is associated with numerous wormian bones in the lambdoid suture. Dr. Macdonell found it in 5.2 per cent. of his Whitechapel skulls and in 11.6 per cent. of the Moorfields series. It is a little interesting to notice that the ophryo-maximal length of the male bathrocephalic skulls is $18 \cdot 1 \mathrm{~cm}$. against $17.7 \mathrm{~cm}$., which is the average for the whole male Hythe series, while in the female skulls the bathrocephalic work out at $17 \cdot 3 \mathrm{~cm}$. against the total average of $17 \cdot 1 \mathrm{~cm}$.

It is evident, however, that this variation is as likely to occur in a series of short English skulls as in a series of long ones.

\section{Scaphocephaly.}

This abnormality is singularly common in the Hythe skulls, occurring in about 6.5 per cent. of them. It is, proportionally, nearly twice as common in males as in females, and does not seem to be affected by the skull being over or under forty years of age.

I have not been able to associate this condition with premature closure of the sagittal suture, though, in several cases, it co-exists with a persistent metopic suture, and then is usually more marked in the frontal region.

From a careful observation of these scaphocephalic and bathrocephalic skulls I cannot help feeling a suspicion that the condition may be accentuated by, if it is 
not due to, postmortem pressure, especially when skulls are stacked in heaps. Vertical pressure would accentuate bathrocephaly while lateral pressure, when the skull is on its side, might increase scaphocephaly by pressing the lower ends of the parietals toward one another. I cannot find, however, that the scaphocephalic skulls are markedly narrower than the others, while in one or two cases, though very rarely, the two abnormalities co-exist, so that, at present, I have no proof whatever of my suspicion.

\section{Plagiocephaly.}

Plagiocephaly was found in eight cases: three males, four females and one child. In three of these its occurrence could be traced to early closure of one-half of the coronal suture, in all cases the left half. In the other examples the sutures were either not closed at all, as in the child, or all closed.

\section{Metopism.}

Altogether there are fifty-two cases of unclosed or partly closed metopic sutures in the 590 skulls-practically 9 per cent. The percentage does not appreciably differ in the two sexes.

Under twenty years of age the percentage is 20.8 . Between twenty and forty it is 9.8 per cent., while over forty it is only found in 6.4 per cent.

Dr. Macdonell calls attention to the fact that the late closure of this suture allows the frontal region of the skull to broaden. I have gone into this and find that he is perfectly right, because the average frontal breadth of the metopic skulls, excluding the children, is $10.4 \mathrm{~cm}$., while the average adult frontal breadth of the two sexes is $9.8 \mathrm{~cm}$. There is, therefore, an average gain of $6 \mathrm{~mm}$. in metopic skulls of this series, against 2 to $3 \mathrm{~mm}$. in the Whitechapel series. The metopic skulls have also an average increase of $1.3 \mathrm{~mm}$. in the greatest parietal breadth.

I have twice found the suture co-existing with marked post coronal depression though this is probably only a coincidence.

\section{Mastoid Suture.}

The suture on the external surface of the mastoid process, caused by the overlapping of a scale-like plate of the squamous part of the temporal bone, was seen as a perfectly evident structure in about 9 per cent. of these skulls. It is difficult, however, to give a definite percentage, since, when once the eye has become used to looking for it, traces can be found very much oftener, indeed, in nearly half the skulls examined.

\section{Post Coronal Depression.}

I only found six well marked cases of this among the 590 skulls, and am sure that, in any case, it is not nearly so common as among the London crania recorded by Macdonell : just as in his skulls the abnormality was most frequent in women, there being four female to two male instances of it. 


\section{Pterion and Epipteric Ossicle.}

In those cases in which no ossicle existed the parietal bone always articulated with the alisphenoid. In all the 590 skulls I saw no example of the temporal articulating with the frontal. In one case only did the four bones meet in one point, and that was on the right side.

Fifty-five skulls out of the 590 have pterionic ossicles or epipteric bones on one or both sides ( 9.3 per cent.). Of these, 28 had a bone on the right side only, 11 on the left side only, while in 16 there was one on each side. It is remarkable that the proportion of epipteric bones is, in this collection, more than twice as great in females as it is in males.

I regard this marked preference of the epipteric bone for the right side and female sex as more than a mere chance, and believe that it is worth while seeking an explanation.

Occasionally, more than one epipteric bone may be present. I met with one case of three on the right side and another of three on the left. The distribution of these bones may be tabulated in the following way :-

Table 6 (Frequence of Epipteric Bones).

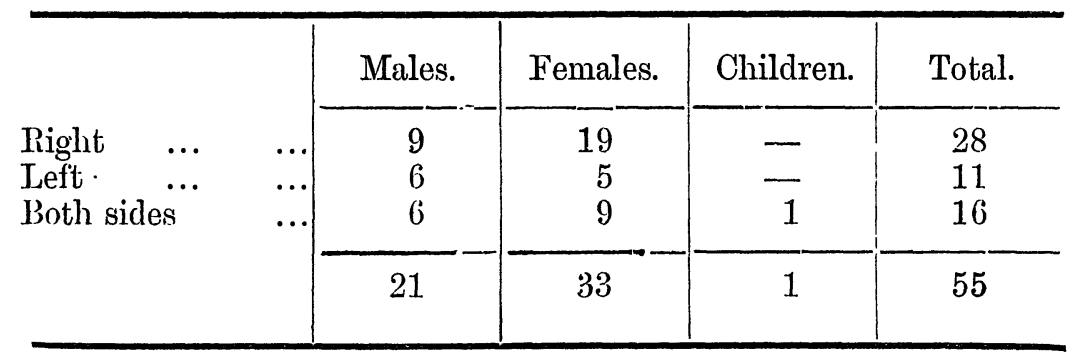

Astcrion Ossicle.

This ossicle, sometimes known as the bone of the lateral fontanelle, is found at the posterior inferior angle of the parietal bone and is not nearly so common as the epipteric. I only saw it in 20 out of the 590 skulls $(3.4$ per cent.). Like the epipteric bone it was nearly twice as common, proportionally, in females as in males, and was also rather more common on the right than on the left side, though, as it was usually bilateral, this was not so apparent as in the former bone.

\section{Table 7 (Frequence of Asterion Ossicle).}

\begin{tabular}{|c|c|c|c|c|c|}
\hline \multirow{3}{*}{$\begin{array}{l}\text { Right } \quad \ldots \\
\text { Left } \quad \ldots \\
\text { Both sides }\end{array}$} & & Males. & Females. & Children. & Total \\
\hline & $\begin{array}{c}\cdots \\
\cdots \\
\ldots \\
\end{array}$ & $\begin{array}{l}2 \\
1 \\
6\end{array}$ & $\begin{array}{l}4 \\
0 \\
7\end{array}$ & $\begin{array}{l}0 \\
0 \\
0\end{array}$ & $\begin{array}{r}6 \\
1 \\
13\end{array}$ \\
\hline & & 9 & 11 & 0 & 20 \\
\hline
\end{tabular}




\section{Bregmatic Ossicle.}

The bregmatic ossicle (os bregme, os antiepilepticum, interfrontal bone) was found six times, three times in each sex. It was, therefore, present in about 1 per cent., which is about the same frequency as in the Whitechapel skulls though less than in those of the Moorfield series, where it was found in nearly 3 per cent. Taking the three series it may be said, provisionally, to be present once in about 75 English skulls.

\section{The Supra-occipital Region.}

The possible subdivisions of the supra-occipital bone are very numerous and no account which I have come across is sufficient to classify all the changes which are rung in this collection. The best account of the various ossicles which I have seen is that by Professor Hepburn of Cardiff (J. Anat. and Phys., Vol. 42, p. 88), and my thanks are due to him for specially directing my attention to this region.

As he points out, the occipito-interparietal suture which sometimes divides the membranous from the cartilaginous part of the supra-occipital is above the superior curved line, sometimes by more than half an inch, but it always seems to start laterally from the asterion.

Remains of this suture are sometimes found, and are usually symmetrical. They run for an inch or two toward the mid-line.

That part of the supra-occipital bone which is above this occipito-interparietal suture, that is to say, the interparietal bone, may be divided by sutures into a median os pentagonale and two lateral ossa triangularia. These have been excellently demonstrated in the photographs of some of Macdonell's Moorfields and Whitechapel crania, and are marked O.P. and O.T., respectively, in his accompany ingdiagram. The sutures between any of these may be obliterated or any one or two of them may be united with the cartilaginous part of the supraoccipital below.

The apex of the supra-occipital bone may be separate and so may form a lambdoid ossicle (L.O.). This varies very greatly in size, but never, as far as I have seen, encroaches on the area of the ossa triangularia. It, in its turn, may be divided into right and left halves, though not always symmetrically; or it may be divided transversely into anterior and posterior parts. To still further complicate the matter the os pentagonale may be divided into lateral halves. of which only one may remain separate.

In one case a small wormian bone was found in the posterior part of the sagittal suture, quite distinct from the various occipital elements, but likely to be mistaken for one of them. This may be a purely fortuitous occurrence, but if it occurs again, it might be convenient to speak of it as the post sagittal ossicle.

The possible combinations of these various bones may be very numerous, bu practically I met with thirteen among the Hythe skulls. 
They are as follows :-

1. Complete interparietal bone (composed of the fused os pentagonale, ossa triangularia and lambdoid ossicle). 1 \%

2. Os pentagonale alone separate. 3 (2 0 1 child).

3. Os pentagnnale and one os triangulare separate. 1 o (L. side).

4. Lateral half of os pentagonale alone separate. 1 \& (L. $\frac{1}{2}$ ).

5. Symmetrical ossa triangularic alone separate. 3 o .

6. Right os triangulare alone separate. $2\left(\begin{array}{llll}1 & 0 & 1 & \text { i }\end{array}\right)$.

7. Left os triangulare alone separate. $2 \delta$.

8. Lateral remnants of parieto-interparietal suture. $\left.4 \begin{array}{llll}3 & \delta & 1 & \text { q }\end{array}\right)$.

9. Lambdoid ossicle alone separate. $13\left(\begin{array}{lllll}1 & 0 & 1 & \text { o } & 1\end{array}\right.$ child $)$.

10. Bilateral lambdoid ossicles. 2 .

11. Lateral half of lambdoid ossicle alone separate. 1 (R. (R. $\left.\frac{1}{2}\right)$.

12. Lambdoid ossicle divided transversely into anterior and posterior parts. 10 .

13. Post sagittal ossicle. 1 .

\section{Odontoid Fucet.}

A facet in the anterior margin of the foramen magnum, for articulation with the odontoid process of the axis, was found six times, four being males and two females.

\section{Paroccipital Process.}

Paroccipital processes were only seen twice. In one case, a male, they were bilateral, while in the other, a female, the process was only present on the left side. In neither case were they long enough to articulate with the transverse process of the atlas.

\section{Conclusions.}

The evidence at my disposal leaves me little doubt that this series of skulls belonged to Kentish men, most of whom lived in the fourteenth and fifteenth centuries; that the skulls and other bones were exhumed, according to the mediæval custom, and stacked in the vault or processional way. They are skulls remarkable for their shortness, though of good breadth and height, and in many of them the occiput is nearly vertical. They more closely resemble the Bavarian, or a combination of the Bavarian and Würtemberg skulls, the measurements of which are given for comparison, than they do the Whitechapel or Moorfields crania. They entirely fail to substantiate the theory which Dr. Macdonell advances that, during the last two or three centuries, a marked change has been going on in the shape of English skulls; that their length has been decreasing while their breadth has increased.

As far as we know, neither Dr. Macdonell nor I have any right to assume that our series are representative of English skulls as a whole. He has shown most 
successfully what the skull of the seventeenth century Londoner was like. I have tried to show what the East Kent man's skull was like a couple of centuries earlier.

Neither of us has done anything more. We are still in ignorance of the skull shapes of other parts of England in the past, and, until we can get some more long series of measurements taken by people with some experience, we had much better realize this fact.

MALES.

\begin{tabular}{|c|c|c|c|c|c|c|c|c|c|c|}
\hline No. & 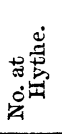 & 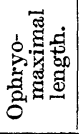 & 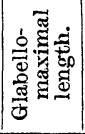 & 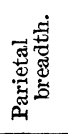 & 营 & 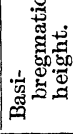 & 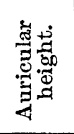 & 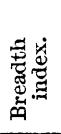 & 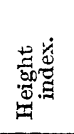 & \\
\hline 1 & 4 & 168 & 171 & 143 & 100 & 140 & 122 & 851 & 833 & \\
\hline 2 & 5 & 179 & 179 & 150 ? & 97 & 131 & & 838 & 732 & Metopic. Sniall lambdoid ossicle. \\
\hline 3 & 6 & 175 & 176 & 136 & 90 & 133 & 117 & 775 & 760 & $\begin{array}{l}\text { Slightly bathrocephalic with wor- } \\
\text { mian bones. }\end{array}$ \\
\hline 4 & 14 & 168 & 171 & 140 & 101 & 126 & 117 & 833 & 750 & Scaphocephalic. \\
\hline 5 & 15 & 177 & 177 & 144 & 100 & 134 & 118 & 814 & 757 & Metopic. \\
\hline 6 & 18 & 175 & 178 & 135 & 98 & 125 & 112 & 771 & 714 & Asterion ossicle on right side. \\
\hline 7 & 36 & 170 & 172 & 144 & 102 & 129 & 118 & 847 & 759 & \\
\hline 8 & 45 & 177 & 175 & 153 & 104 & 144 & 129 & 864 & 814 & $\begin{array}{l}\text { Symmetrical ossa triangularia in } \\
\text { occipital. }\end{array}$ \\
\hline 9 & 49 & 177 & 180 & 147 & 107 & 144 & 127 & 831 & 814 & $\begin{array}{l}\text { Epipteric bone on right side. } \\
\text { Some bathrocephaly without } \\
\text { wormian bones. }\end{array}$ \\
\hline 10 & 60 & 170 & 170 & 141 & 100 & 124 & 118 & 799 & 729 & \\
\hline 11 & 61 & 183 & 184 & 139 & 95 & 141 & 125 & 760 & 770 & $\begin{array}{l}\text { Scaphocephalic. Bathrocephalic. } \\
\text { Lambdoid ossicle. }\end{array}$ \\
\hline 12 & 83 & 172 & 171 & 150 & 98 & 127 & 120 & 872 & 738 & Epipteric bone on left side. \\
\hline 13 & 100 & 167 & 170 & 142 & 94 & 125 & 112 & 850 & 749 & \\
\hline ? 14 & 101 & 171 & 170 & 142 & 93 & 135 & 125 & 830 & 789 & \\
\hline 15 & 102 & 166 & 167 & 151 & 98 & 133 & 125 & 910 & 801 & \\
\hline 16. & 104 & 187 & 185 & 154 & 109 & & & 824 & - & $\begin{array}{c}\text { Metopic. } \\
\text { occipital. }\end{array}$ Os pentagonale in \\
\hline 17 & 112 & 180 & 183 & 142 & 95 & 128 & 112 & 789 & 711 & Scaphocephalic. \\
\hline 18 & 113 & 170 & 172 & 141 & 100 & 138 & 122 & 829 & 812 & \\
\hline 19 & 114 & 181 & 180 & 149 & 103 & 138 & 129 & 823 & 762 & \\
\hline 20 & 120 & 172 & 172 & 144 & 98 & 135 & 123 & 837 & 785 & \\
\hline 21 & 132 & 182 & 183 & 140 & 99 & 126 & 116 & 769 & 692 & $\begin{array}{l}\text { Metopic. Depression just behind } \\
\text { bregma. Palatine torus. }\end{array}$ \\
\hline 22 & 155 & 183 & 183 & 144 & 98 & 135 & 122 & 787 & 738 & $\begin{array}{l}\text { Bathrocephalic with wormian } \\
\text { bones. }\end{array}$ \\
\hline 23 & 161 & 180 & 180 & 131 & 95 & 131 & 120 & 728 & 728 & Scaphocephalic. \\
\hline$? 24$ & 171 & 172 & 171 & 143 & 98 & 140 & 120 & 831 & 814 & \\
\hline 25 & 173 & 169 & 172 & 143 & 104 & 128 & 120 & 846 & 757 & \\
\hline 26 & 175 & 181 & 181 & 145 & 94 & 137 & 123 & 801 & 7507 & $\begin{array}{l}\text { Bathrocephalic without wormian } \\
\text { bones. Epipteric bone on right } \\
\text { side. }\end{array}$ \\
\hline 27 & 178 & 183 & 183 & 142 & 93 & 129 & 119 & 776 & 705 & \\
\hline 28 & 188 & 187 & 188 & 141 & 92 & 137 & 119 & 754 & 733 & Scaphocephalic. \\
\hline 29 & 189 & 185 & 187 & 150 & 97 & 135 & & 811 & 730 & Metopic. Small lambdoid ossicle. \\
\hline 30 & 192 & 184 & 185 & 143 & 100 & 139 & 119 & 777 & 755 & \\
\hline 31 & 197 & 177 & 179 & 134 & 94 & 127 & 114 & 757 & 718 & $\begin{array}{l}\text { Markedly scaphocephalic. Epip- } \\
\text { teric bone on left side. }\end{array}$ \\
\hline 32 & 207 & 176 & 179 & 143 & 99 & 140 & 122 & 813 & 795 & \\
\hline 33 & 209 & 179 & 183 & 147 & 101 & 133 & 126 & 821 & 743 & \\
\hline 34 & 210 & 174 & 176 & 138 & 98 & 129 & $\overline{1}$ & 793 & 741 & \\
\hline 35 & 214 & 166 & 167 & 139 & 98 & 132 & $115 ?$ & 837 & 795 & \\
\hline
\end{tabular}


MALES-continued.

\begin{tabular}{|c|c|c|c|c|c|c|c|c|c|c|}
\hline No. & 䓂 & 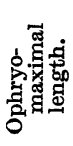 & 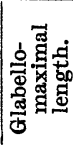 & 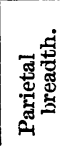 & 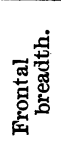 & 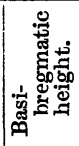 & 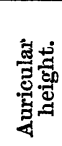 & 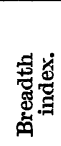 & 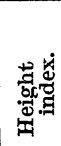 & \\
\hline 36 & 215 & 195 & 197 & 146 & 95 & 130 & 121 & 749 & 667 & \\
\hline 37 & 217 & 168 & 169 & 147 & 100 & 133 & 123 & 875 & 792 & Epipteric bone on right side. \\
\hline 38 & 221 & 183 & 183 & 138 & 97 & 132 & 119 & 754 & 721 & \\
\hline 39 & 223 & 173 & 177 & 139 & 102 & 145 & 126 & 803 & 838 & Scaphocephalic. \\
\hline 40 & 225 & 177 & 178 & 139 & 96 & 132 & 125 & 785 & 746 & Epipteric bone on left side. \\
\hline 41 & 226 & 167 & 170 & 127 & 95 & 128 & 111 & 760 & 766 & Scaphocephalic. \\
\hline 42 & 227 & 172 & 176 & 134 & 87 & 124 & 108 & 779 & 721 & \\
\hline 43 & 233 & 181 & 182 & 140 & 103 & 135 & 117 & 773 & 746 & \\
\hline 44 & 237 & 170 & 171 & 143 & 93 & 129 & 118 & 841 & 759 & \\
\hline 45 & 238 & 178 & 182 & 145 & 92 & 134 & & 815 & 753 & \\
\hline 46 & 244 & 192 & 195 & 147 & 106 & 144 & 125 & 766 & 750 & $\begin{array}{l}\text { Plagiocephalic without closure of } \\
\text { coronal snture. }\end{array}$ \\
\hline 47 & 252 & 190 & 190 & 151 & - & 142 & 130 & 795 & 747 & $\begin{array}{l}\text { Bathrocephalic with wormian } \\
\text { bones. }\end{array}$ \\
\hline 48 & 254 & 189 & 188 & 141 & 105 & 129 & 121 & 746 & 683 & \\
\hline 49 & 256 & 181 & 184 & 140 & 97 & 128 & 111 & 773 & 707 & \\
\hline$? 50$ & 263 & 173 & 172 & 145 & 95 & 136 & 118 & 838 & 786 & $\begin{array}{l}\text { Bathrocephalic. Jarge os triangu- } \\
\text { lare on left side. }\end{array}$ \\
\hline 51 & 264 & 179 & 181 & 140 & 102 & 137 & 122 & 782 & 765 & \\
\hline$? 52$ & 269 & 164 & 163 & 133 & 93 & 130 & 112 & 811 & 793 & \\
\hline 53 & 270 & 179 & 179 & 152 & 107 & 134 & 122 & 849 & 749 & Metopic. \\
\hline 54 & 271 & 181 & 181 & 144 & 100 & 128 & 116 & 796 & 707 & \\
\hline 55 & 273 & 164 & 164 & 137 & 97 & 125 & 113 & 835 & 762 & \\
\hline 56 & 275 & 179 & 182 & 142 & 99 & 131 & 119 & 793 & 732 & \\
\hline 57 & 277 & 171 & 170 & 150 & 95 & 129 & 123 & 877 & 754 & \\
\hline 58 & 283 & 181 & 185 & 145 & 98 & 142 & 124 & 801 & 785 & \\
\hline 59 & 288 & 178 & 179 & 147 & 102 & 133 & 116 & 826 & 747 & \\
\hline 60 & 292 & 171 & 173 & 131 & 93 & 126 & 111 & 766 & 737 & $\begin{array}{l}\text { Half lambdoid ossicle on right side } \\
\text { of lambda. }\end{array}$ \\
\hline 61 & 294 & 176 & 179 & 142 & 99 & 128 & 114 & 807 & 727 & Bathrocephalic. \\
\hline 62 & 297 & 172 & 172 & 133 & 95 & 130 & 114 & 773 & 756 & \\
\hline 63 & 301 & 178 & 178 & 142 & 101 & 139 & 127 & 798 & 781 & \\
\hline 64 & 305 & 176 & 178 & 138 & 97 & 133 & 116 & 784 & 756 & \\
\hline 65 & 308 & 183 & 184 & 150 & 104 & $13 \check{~}$ & 123 & 820 & 738 & \\
\hline 66 & 320 & 176 & 176 & 148 & 100 & 138 & 128 & 841 & 784 & $\begin{array}{l}\text { Slightly scaphocephalic. Epipteric } \\
\text { bone on each side. }\end{array}$ \\
\hline 67 & 321 & 170 & 171 & 138 & 102 & 130 & 118 & 812 & 765 & \\
\hline 68 & 329 & 173 & 172 & 144 & 97 & 132 & 118 & 832 & 763 & $\begin{array}{l}\text { Asterion ossicle on each side } \\
\text { Palatine torus. }\end{array}$ \\
\hline 69 & 340 & 183 & 185 & 148 & 102 & 138 & 125 & 809 & 754 & \\
\hline 70 & 342 & 176 & 178 & 131 & 97 & 129 & 112 & 744 & 733 & $\begin{array}{l}\text { Bathrocephalic without wormian } \\
\text { bones. }\end{array}$ \\
\hline 71 & 345 & 178 & 178 & 143 & 94 & 130 & 120 & 803 & 730 & \\
\hline 72 & 346 & 179 & 179 & 148 & 100 & 137 & 125 & 827 & 765 & $\begin{array}{l}\text { Slightly bathrocephalic. Asterion } \\
\text { ossicle on each side. }\end{array}$ \\
\hline 73 & 347 & 181 & 182 & 143 & 99 & 129 & 119 & 790 & 713 & \\
\hline 74 & 358 & 175 & 176 & 148 & 87 & 132 & 120 & 846 & 754 & \\
\hline 75 & 363 & 177 & 177 & 139 & 104 & 135 & 119 & 785 & 763 & \\
\hline 76 & 368 & 178 & 18 & 139 & 102 & 138 & 119 & 781 & 775 & \\
\hline 77 & 372 & 189 & 189 & 141 & 102 & 131 & 122 & 746 & 693 & \\
\hline 78 & 386 & 160 & 160 & 140 & 95 & 124 & 116 & 875 & 775 & \\
\hline$? 79$ & 387 & 167 & 166 & 138 & 96 & 135 & 120 & 826 & 808 & $\begin{array}{l}\text { Slight palatine torus. Epipteric } \\
\text { bone on right side. Paroccipital }\end{array}$ \\
\hline 80 & 388 & 173 & 173 & 150 & 99 & 130 & 126 & 867 & 751 & $\begin{array}{l}\text { Slight plagiocephaly without } \\
\text { obliteration of sutures }\end{array}$ \\
\hline 81 & 389 & 173 & 174 & 145 & 95 & 131 & 120 & 838 & 757 & Epipteric bone on left side. \\
\hline 82 & 392 & 170 & 173 & 138 & 99 & 136 & 119 & 812 & 800 & Odontoid facet. Palatine torus. \\
\hline
\end{tabular}


MALES-continued.

\begin{tabular}{|c|c|c|c|c|c|c|c|c|c|c|}
\hline No. & 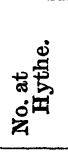 & 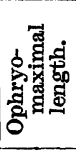 & 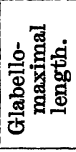 & 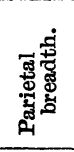 & 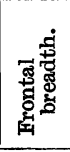 & 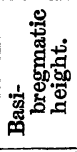 & 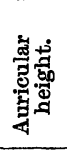 & 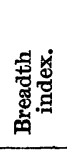 & 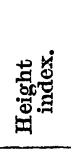 & \\
\hline 83 & 395 & 176 & 176 & 136 & 98 & 132 & 118 & 773 & 750 & Metopic. Scaphocephalic. \\
\hline 84 & 397 & 181 & 181 & 150 & 102 & 130 & 120 & 829 & 718 & $\begin{array}{l}\text { Os pentagonate and left os trian- } \\
\text { gulare. }\end{array}$ \\
\hline 85 & 400 & 169 & 172 & 140 & 97 & 132 & 115 & 828 & 781 & $\begin{array}{l}\text { Os bregmoe. Bathrocephaly with } \\
\text { wormian bones. }\end{array}$ \\
\hline 86 & 405 & 179 & 178 & 149 & 104 & 141 & 128 & 832 & 788 & Epipteric bone on each side. \\
\hline 87 & 406 & 171 & 174 & 142 & 97 & 141 & 121 & 830 & 825 & $\begin{array}{l}\text { Pterion comes to a point on right } \\
\text { side. }\end{array}$ \\
\hline 88 & 413 & 173 & 173 & 148 & 102 & 133 & 121 & 855 & 769 & Metopic. \\
\hline 89 & 415 & 177 & 177 & 148 & 97 & 136 & 123 & 836 & 768 & \\
\hline 90 & 416 & 179 & 181 & 140 ? & 98 & 125 & 119 & 782 & 698 & Metopic. \\
\hline 91 & 423 & 187 & 188 & 145 & 108 & 135 & 128 & 775 & 722 & $\begin{array}{l}\text { Bathrocephaly with wormian } \\
\text { bones. }\end{array}$ \\
\hline 92 & 426 & 188 & 188 & 142 & $9 \tilde{\mathfrak{g}}$ & 139 & 118 & 755 & 739 & Asterion ossicle each side. \\
\hline 93 & 427 & 186 & 185 & 145 & 105 & 141 & 128 & 780 & 758 & $\begin{array}{l}\text { Asterion ossicle left side. Small } \\
\text { lambdoid ossicle. }\end{array}$ \\
\hline 94 & 433 & 174 & 176 & 141 & 96 & 136 & 123 & 810 & 782 & \\
\hline 95 & 437 & 168 & 169 & 143 & 91 & 126 & 117 & 851 & 750 & \\
\hline 96 & 439 & 182 & 184 & $144 ?$ & 104 & 129 & 115 & 791 & 709 & Epipteric bone on left side. \\
\hline 97 & 441 & 173 & 173 & 145 & 100 & 136 & 124 & 838 & 786 & Depression behind bregma. \\
\hline 98 & 442 & 173 & 178 & 142 & 98 & 130 & 116 & 821 & 751 & \\
\hline 99 & 452 & 173 & 175 & 145 & 95 & 119 & 115 & 838 & 688 & $\begin{array}{l}\text { Bathrocephaly with wornian } \\
\text { bones. Left os triangulare. }\end{array}$ \\
\hline 100 & 453 & 170 & 171 & 131 & 97 & 127 & 111 & 771 & 747 & Scaphocephalic. \\
\hline 10 & 591 & 173 & 177 & 151 & 107 & 140 & 122 & 873 & 809 & \\
\hline 10 & 454 & 164 & 166 & 142 & 10 & 125 & & 866 & 762 & \\
\hline $\begin{array}{l}103 \\
104\end{array}$ & 455 & 173 & 175 & 131 & 101 & 131 & 16 & 757 & 757 & \\
\hline $\begin{array}{l}104 \\
105\end{array}$ & 461 & 168 & 167 & 141 & 10 & 129 & & & 768 & \\
\hline $\begin{array}{l}105 \\
? 106\end{array}$ & 471 & 171 & 173 & 134 & 97 & 132 & 111 & 784 & 772 & Lambdoid ossicle. \\
\hline $\begin{array}{l}\text { ? } 106 \\
107\end{array}$ & 475 & 168 & 168 & 143 & 92 & 122 & 116 & 851 & 726 & \\
\hline 107 & 478 & 173 & 177 & 133 & 89 & 133 & 118 & 769 & 769 & $\begin{array}{l}\text { Bathrocepalic with wormian bones } \\
\text { and lambdoid ossicle. }\end{array}$ \\
\hline $\begin{array}{l}108 \\
109\end{array}$ & $\begin{array}{l}484 \\
485\end{array}$ & 169 & 173 & 136 & 95 & 132 & 116 & 805 & 781 & \\
\hline 109 & 485 & 185 & 186 & 137 & 96 & 125 & 117 & 741 & 676 & $\begin{array}{l}\text { Scapbocephalic. Epipteric bone on } \\
\text { right side. }\end{array}$ \\
\hline $\begin{array}{l}110 \\
111\end{array}$ & 487 & 179 & 180 & 133 & 95 & 124 & 112 & 743 & 693 & \\
\hline 111 & 496 & 166 & 168 & 146 & 102 & 129 & 115 & 880 & 777 & $\begin{array}{l}\text { Asterion ossicle each side. Inter- } \\
\text { parietal suture near asterion each } \\
\text { side. }\end{array}$ \\
\hline 112 & 503 & 178 & 179 & 140 & 95 & 131 & 119 & 787 & 736 & $\begin{array}{l}\text { Bathrocephaly without wormian } \\
\text { bones. }\end{array}$ \\
\hline 113 & 510 & 175 & 178 & 133 & 93 & 125 & 113 & 760 & 714 & \\
\hline $\begin{array}{l}114 \\
115\end{array}$ & $\begin{array}{l}521 \\
525\end{array}$ & $\begin{array}{l}180 \\
186\end{array}$ & $\begin{array}{l}183 \\
185\end{array}$ & $\begin{array}{l}144 \\
161\end{array}$ & $\begin{array}{l}103 \\
107\end{array}$ & 135 & 116 & $\begin{array}{l}800 \\
866\end{array}$ & $\underline{750}$ & $\begin{array}{l}\text { Metopic. Epipteric bone on right. } \\
\text { Os trianqulare on right. }\end{array}$ \\
\hline 116 & 544 & 166 & 171 & 140 & 94 & 128 & 119 & 843 & 771 & Odontoid facet. \\
\hline $\begin{array}{l}117 \\
118\end{array}$ & 548 & 171 & 172 & 147 & 101 & 134 & 117 & 860 & 784 & \\
\hline 118 & 555 & 182 & 183 & 140 & 95 & 126 & - & 769 & 692 & $\begin{array}{l}\text { Scaphocephalic. Epipteric bone } \\
\text { left. }\end{array}$ \\
\hline ? 119 & 559 & 173 & 171 & 150 & 102 & 134 & - & 867 & 775 & $\begin{array}{l}\text { Vestige of interparietal suture } \\
\text { near asterion on each side. }\end{array}$ \\
\hline 120 & 565 & 172 & 174 & 142 & 95 & 137 & - & 826 & 797 & $\begin{array}{l}\text { Two lambdoid ossicles (antero- } \\
\text { posterior). }\end{array}$ \\
\hline 121 & 568 & 185 & 183 & 147 & 94 & - & - & 795 & - & $\begin{array}{l}\text { Bathrocephalic with lambdoid } \\
\text { ossicle and other wormian bones } \\
\text { in lambdoid suture. }\end{array}$ \\
\hline 122 & 575 & 167 & 172 & 146 & 98 & 130 & 116 & 874 & 778 & \\
\hline 123 & 576 & 171 & 171 & 146 & 100 & 132 & 118 & 854 & 772 & \\
\hline
\end{tabular}


MALES-continued.

\begin{tabular}{|c|c|c|c|c|c|c|c|c|c|c|}
\hline No. & 密 & 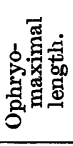 & 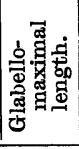 & 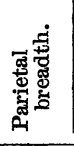 & 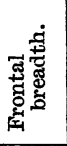 & 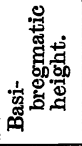 & 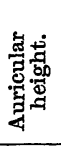 & 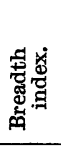 & 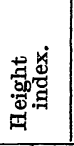 & \\
\hline 124 & 578 & $17 \tilde{5}$ & - & 154 & - & 137 & 128 & 880 & 783 & \\
\hline 125 & 589 & 184 & 184 & 158 & 108 & 151 & 136 & 859 & 821 & \\
\hline 126 & 7 & 181 & 182 & 138 & 100 & 131 & 117 & 762 & 724 & Metopic. \\
\hline 127 & 9 & 186 & 186 & 147 & 104 & - & $\overline{125}$ & 790 & $\overline{790}$ & \\
\hline 128 & 12 & 176 & 178 & 136 & 92 & 139 & 125 & 773 & 790 & $\begin{array}{l}\text { Odontoid facet. Slightly sciphoce- } \\
\text { phalic. }\end{array}$ \\
\hline $\begin{array}{l}129 \\
130\end{array}$ & $\begin{array}{l}13 \\
16\end{array}$ & $\begin{array}{l}182 \\
182\end{array}$ & 186 & 147 & $\begin{array}{r}103 \\
97\end{array}$ & $125 ?$ & 121 & 808 & $687 ?$ & \\
\hline $\begin{array}{l}130 \\
131\end{array}$ & $\begin{array}{l}16 \\
17\end{array}$ & $\begin{array}{l}182 \\
180\end{array}$ & 184 & $\begin{array}{l}147 \\
140\end{array}$ & $\begin{array}{l}97 \\
96\end{array}$ & $\overline{199}$ & 118 & 808 & $\overline{717}$ & \\
\hline $\begin{array}{l}131 \\
132\end{array}$ & 19 & 178 & $\begin{array}{l}181 \\
182\end{array}$ & $\begin{array}{l}140 \\
151\end{array}$ & 102 & - & 119 & $\begin{array}{l}778 \\
848\end{array}$ & 717 & \\
\hline 133 & 22 & 179 & 180 & 147 & 96 & 138 & - & 821 & 771 & \\
\hline 134 & 23 & 185 & 184 & 157 & 109 & 138 & 120 & 849 & 746 & Metopic. \\
\hline 135 & 27 & 175 & 177 & 141 & 97 & 135 & 120 & 806 & 771 & \\
\hline 136 & 28 & 182 & 183 & 151 & - & 132 & 123 & 830 & 725 & \\
\hline 137 & 29 & 170 & 173 & 144 & 98 & 137 & 123 & 847 & 806 & \\
\hline 138 & 30 & 175 & 179 & 144 & 103 & 137 & 120 & $\begin{array}{l}823 \\
768\end{array}$ & 783 & \\
\hline 139 & 32 & 190 & 192 & 146 & - & 135 & - & 768 & 711 & $\begin{array}{l}\text { Metopic suture open externally } \\
\text { above. }\end{array}$ \\
\hline 140 & 35 & 181 & 181 & 139 & 103 & 138 & 123 & 768 & 762 & $\begin{array}{l}\text { Slightly bathrocephalic without } \\
\text { wormian bones. }\end{array}$ \\
\hline $1+1$ & 37 & 182 & 184 & 145 & - & 144 & 120 & 797 & 791 & Scaphocephalic. \\
\hline $\begin{array}{l}142 \\
143\end{array}$ & 38 & 172 & 173 & 143 & - & 135 & 123 & 831 & 785 & \\
\hline 143 & 41 & 187 & 189 & 143 & 107 & 143 & 130 & 765 & 765 & $\begin{array}{l}\text { Slightly bathrocephalic with worm- } \\
\text { ian bones. }\end{array}$ \\
\hline $\begin{array}{l}144 \\
145\end{array}$ & $\begin{array}{l}42 \\
43\end{array}$ & $\begin{array}{l}180 \\
175\end{array}$ & $\begin{array}{l}178 \\
175\end{array}$ & $\begin{array}{l}147 \\
151\end{array}$ & $\begin{array}{l}107 \\
103\end{array}$ & $\begin{array}{l}132 \\
134\end{array}$ & 124 & 817 & 733 & \\
\hline 146 & $\begin{array}{l}40 \\
46\end{array}$ & $\begin{array}{l}170 \\
182\end{array}$ & $\begin{array}{l}175 \\
182\end{array}$ & $\begin{array}{l}151 \\
154\end{array}$ & $\begin{array}{l}103 \\
103\end{array}$ & $\begin{array}{l}134 \\
136\end{array}$ & $\begin{array}{l}121 \\
128\end{array}$ & $\begin{array}{l}863 \\
846\end{array}$ & $\begin{array}{l}766 \\
747\end{array}$ & \\
\hline 147 & 48 & 190 & 192 & 147 & 95 & 135 & 122 & 774 & 711 & \\
\hline 148 & 50 & 167 & 169 & 147 & 101 & 136 & 123 & 880 & 814 & \\
\hline 149 & 51 & 184 & 187 & 144 & 103 & 142 & 123 & 783 & 772 & $\begin{array}{l}\text { Bathrocephalic with wormian } \\
\text { bones. }\end{array}$ \\
\hline $\begin{array}{l}150 \\
151\end{array}$ & 53 & 184 & 188 & 147 & 107 & 142 & 128 & 803 & 776 & \\
\hline $\begin{array}{l}151 \\
152\end{array}$ & 55 & 173 & 173 & 147 & 101 & 138 & 125 & 850 & 798 & \\
\hline 152 & 56 & 190 & 192 & 144 & 99 & 134 & 121 & 758 & 705 & $\begin{array}{l}\text { Symmetrical ossa triangularica in } \\
\text { occipital region. }\end{array}$ \\
\hline 153 & 57 & 179 & 179 & 146 & 106 & 147 & 127 & 816 & 821 & \\
\hline & 58 & 185 & 187 & 148 & 105 & 140 & 126 & 800 & 757 & \\
\hline $\begin{array}{l}\text { ? } 155 \\
156\end{array}$ & 59 & 179 & 177 & 143 & 107 & 138 & 122 & 799 & 771 & \\
\hline $\begin{array}{l}106 \\
157\end{array}$ & $\begin{array}{l}63 \\
66\end{array}$ & $\begin{array}{l}167 \\
165\end{array}$ & $\begin{array}{l}170 \\
171\end{array}$ & $\begin{array}{l}145 \\
153\end{array}$ & $\begin{array}{r}97 \\
101\end{array}$ & $\begin{array}{l}142 \\
135\end{array}$ & $\begin{array}{l}126 \\
123\end{array}$ & $\begin{array}{l}868 \\
927\end{array}$ & $\begin{array}{l}850 \\
818\end{array}$ & Epipteric bone on right side. \\
\hline 15 & 67 & 176 & 178 & 149 & 101 & - & 120 & 847 & - & Bathrocepalic with wormian bones. \\
\hline 159 & 69 & 178 & 180 & 136 & 97 & 130 & 117 & 764 & 730 & \\
\hline 160 & 70 & 180 & 181 & 146 & 104 & 137 & 118 & 811 & 761 & \\
\hline 16 & 72 & 179 & 183 & 142 & 91 & $\overline{197}$ & $\overline{115}$ & $\begin{array}{l}793 \\
843\end{array}$ & $\overline{738}$ & \\
\hline $\begin{array}{l}162 \\
163\end{array}$ & $\begin{array}{l}75 \\
76\end{array}$ & $\begin{array}{l}172 \\
175\end{array}$ & $\begin{array}{l}172 \\
174\end{array}$ & $\begin{array}{l}145 \\
141\end{array}$ & $\begin{array}{r}96 \\
102\end{array}$ & $\begin{array}{l}127 \\
124\end{array}$ & $\begin{array}{l}115 \\
117\end{array}$ & $\begin{array}{l}843 \\
806\end{array}$ & $\begin{array}{l}738 \\
709\end{array}$ & $\begin{array}{l}\text { Metoplc suture open externally. } \\
\text { Metopic suture but also open }\end{array}$ \\
\hline 164 & 77 & 175 & 176 & 151 & 105 & 124 & 125 & 863 & 709 & Metopic suture open externally. \\
\hline 165 & 81 & 177 & 181 & 143 & 98 & 134 & 121 & 808 & 757 & \\
\hline 166 & 82 & 173 & 174 & 141 & 104 & 132 & 115 & 815 & 763 & $\begin{array}{l}\text { Scaphocephalic. Metopic suture } \\
\text { open externally. }\end{array}$ \\
\hline 167 & 86 & 173 & 174 & 134 & 92 & 135 & 116 & 775 & 780 & Diamond-shaped os pentagonale. \\
\hline 168 & 90 & 183 & 182 & 151 & 112 & 138 & 128 & 825 & 754 & Scaphocephalic. \\
\hline 169 & 91 & 180 & 183 & 146 & 105 & 143 & 124 & 811 & 794 & \\
\hline 170 & 93 & 177 & 179 & 144 & 100 & 130 & 116 & 814 & 734 & Bathrocephalic with wormian bones. \\
\hline 171 & 94 & 192 & 192 & 143 & 100 & 142 & 126 & 745 & 740 & $\begin{array}{l}\text { Bathrocephalic with wormian } \\
\text { bones. Scaphocephalic. }\end{array}$ \\
\hline 172 & 95 & 170 & 172 & 149 & 102 & 130 & 121 & 876 & 765 & \\
\hline
\end{tabular}


MALES-continued.

\begin{tabular}{|c|c|c|c|c|c|c|c|c|c|c|}
\hline No. & 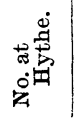 & 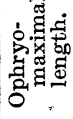 & 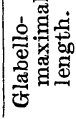 & 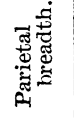 & 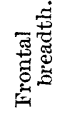 & 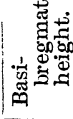 & 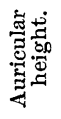 & 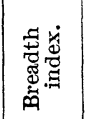 & 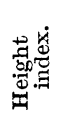 & \\
\hline 173 & 96 & 177 & 178 & 147 & 99 & 132 & 119 & 831 & 746 & Bathrocephalic. \\
\hline 174 & 97 & 192 & 194 & 148 & 100 & 128 & 122 & 771 & 667 & \\
\hline 175 & 98 & 190 & 192 & 141 & 104 & - & 122 & 742 & - & \\
\hline 176 & 99 & 183 & 185 & 142 & 97 & 140 & 119 & 776 & 765 & \\
\hline 177 & 103 & 179 & 178 & 143 & 102 & 125 & 110 & 799 & 698 & Metopic. \\
\hline 178 & 105 & 185 & 188 & 153 & 101 & 135 & 119 & 827 & 719 & Traces of metopic suture externally. \\
\hline 179 & 106 & 172 & 173 & 161 & 111 & 138 & 129 & 936 & 802 & \\
\hline 180 & 109 & 187 & 192 & 141 & 93 & 126 & 109 & 754 & 674 & \\
\hline 181 & 111 & 163 & 166 & 142 & 99 & 127 & 116 & 871 & 779 & \\
\hline 182 & 121 & 184 & 184 & 149 & 106 & 137 & 124 & 810 & 745 & \\
\hline 183 & 122 & 164 & 169 & 142 & 107 & 131 & - & 866 & 799 & \\
\hline 184 & 125 & 174 & 177 & 151 & 94 & 126 & 119 & 868 & 724 & \\
\hline 185 & 128 & 176 & 178 & 145 & 96 & 134 & 120 & 824 & 761 & $\begin{array}{l}\text { Bathrocephalic with wormian } \\
\text { bones. }\end{array}$ \\
\hline 186 & 134 & 179 & 180 & 147 & 105 & 137 & 125 & .821 & 765 & $\begin{array}{l}\text { Bathrocephalic with wormian } \\
\text { bones. }\end{array}$ \\
\hline 187 & 138 & 188 & 189 & 141 & 99 & 134 & 119 & 750 & 713 & \\
\hline 188 & 140 & 183 & 187 & 136 & 98 & 134 & 118 & 743 & 732 & \\
\hline 189 & 158 & 180 & 181 & 135 & 96 & 125 & 122 & 750 & 694 & Epipteric bone on right side. \\
\hline 190 & $\cdot 160$ & 174 & 175 & 136 & 98 & 143 & 124 & 782 & 822 & \\
\hline 191 & 163 & 190 & 191 & 141 & 101 & 128 & 126 & 742 & 674 & Bathrocephalic. \\
\hline 192 & 165 & 170 & 170 & 150 & 101 & 136 & 127 & 882 & 800 & Epipteric bone on each side. \\
\hline 193 & 166 & 176 & 177 & 141 & 95 & 137 & 122 & 801 & 778 & \\
\hline 194 & 168 & 177 & 178 & 147 & 101 & 135 & 121 & 831 & 763 & \\
\hline 195 & 172 & 180 & 181 & 143 & 98 & 135 & 123 & 794 & 750 & Scaphocephalic. \\
\hline 196 & 174 & 174 & 177 & 145 & 103 & 142 & & 833 & 816 & \\
\hline 197 & 179 & 178 & 176 & 146 & 94 & 135 & 125 & 820 & 755 & \\
\hline 198 & 182 & 182 & 184 & 141 & 99 & 138 & 125 & 775 & 758 & Epipteric bone on each side. \\
\hline 199 & 183 & 185 & 189 & 147 & 101 & 134 & 123 & 795 & 724 & \\
\hline 200 & 185 & 185 & 186 & 147 & 103 & 136 & 123 & 795 & 735 & \\
\hline 201 & 190 & 175 & 176 & $150 ?$ & 106 & 133 & 120 & 857 ? & $760 ?$ & Metopic suture open externally. \\
\hline 202 & 201 & 171 & 171 & 141 & 98 & 140 & 120 & 825 & 819 & \\
\hline 203 & $201 \mathrm{~A}$ & 177 & 178 & 143 & 107 & 138 & 121 & 808 & 780 & $\begin{array}{l}\text { Epipteric bone each side. Small } \\
\text { lambdoid ossicle. }\end{array}$ \\
\hline 204 & 203 & 178 & 183 & 144 & 103 & 127 & 119 & 809 & 713 & \\
\hline 205 & 204 & 176 & 178 & 144 & 105 & 138 & 125 & 818 & 784 & Scaphocephalic. \\
\hline 206 & 218 & 185 & 185 & 146 & 108 & 142 & 128 & 789 & 768 & \\
\hline 207 & 222 & 187 & 189 & 147 & 97 & 133 & 124 & 786 & 711 & \\
\hline 208 & 224 & 171 & 173 & 153 & 105 & 136 & 127 & 895 & 795 & \\
\hline 209 & 228 & 170 & 172 & 142 & 98 & 133 & 116 & 835 & 782 & $\begin{array}{l}\text { Trace of interparietal suture near } \\
\text { asterion. }\end{array}$ \\
\hline 210 & 229 & 176 & 177 & 143 & 101 & 139 & 126 & 813 & 790 & \\
\hline 211 & 231 & 183 & 185 & 141 & 98 & 134 & 117 & 770 & 732 & \\
\hline 212 & 234 & 173 & 177 & 128 & 92 & 135 & 120 & 740 & 780 & \\
\hline 213 & 236 & 180 & 179 & 146 & 103 & 136 & 122 & 811 & 756 & $\begin{array}{l}\text { Metopic suture open in upper half } \\
\text { externally, in upper quarter } \\
\text { internally. Os bregmce. Right } \\
\text { ossicle of asterion. }\end{array}$ \\
\hline 214 & 239 & 173 & 178 & 146 & 100 & 133 & 123 & 844 & 769 & $\begin{array}{l}\text { Metopic suture open in lower half } \\
\text { externally. }\end{array}$ \\
\hline 215 & 240 & 178 & 177 & 144 & 96 & 137 & 123 & 809 & 770 & \\
\hline 216 & 241 & 173 & 176 & 137 & 98 & 134 & 121 & 792 & 775 & \\
\hline 217 & 242 & 179 & 183 & 145 & 105 & 138 & 122 & 810 & 771 & \\
\hline 218 & 243 & 181 & 183 & 141 & 101 & 140 & 123 & 779 & 773 & $\begin{array}{l}\text { Slightly bathrocephalic with } \\
\text { wormian bones. }\end{array}$ \\
\hline $219^{\circ}$ & 245 & 181 & 184 & - & 102 & 132 & - & - & 729 & \\
\hline ? 220 & 246 & 169 & 169 & 143 & 97 & 130 & 119 & 846 & 769 & \\
\hline 221 & 247 & 172 & 177 & 144 & 101 & 136 & 327 & 837 & 791 & \\
\hline
\end{tabular}


MALES-continued.

\begin{tabular}{|c|c|c|c|c|c|c|c|c|c|c|}
\hline No. & 密 & 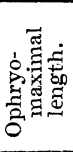 & 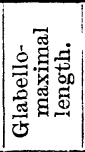 & 焉 & 焉 & 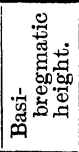 & 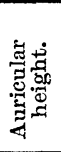 & 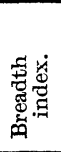 & 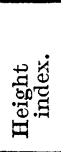 & \\
\hline 222 & 248 & 173 & 177 & - & 108 & 142 & - & - & 821 & \\
\hline 223 & 249 & 180 & 180 & 150 & 103 & 143 & 132 & 833 & 794 & \\
\hline 224 & 250 & 191 & 194 & 142 & 96 & 140 & 131 & 743 & 733 & $\begin{array}{l}\text { Bathrocephalic without wormian } \\
\text { bones. }\end{array}$ \\
\hline 225 & 251 & 184 & 186 & 157 & 107 & 144 & 125 & 853 & 783 & $\begin{array}{l}\text { Plagiocephalic. Sutures all closed } \\
\text { inside. }\end{array}$ \\
\hline 226 & 259 & 173 & 174 & 150 & 104 & 137 & 120 & 867 & 792 & \\
\hline 227 & 261 & 169 & 175 & 134 & 92 & 131 & 118 & 793 & 775 & \\
\hline 228 & 266 & 183 & 187 & 146 & 98 & 142 & 125 & 798 & 776 & Scaphocephalic. \\
\hline 229 & 274 & 170 & 174 & 137 & 92 & 131 & 120 & 806 & 771 & \\
\hline 230 & 279 & 182 & 181 & 152 & 102 & 131 & 118 & 835 & 720 & \\
\hline 231 & 280 & 171 & 174 & 142 & 96 & 120 & 108 & 830 & 702 & \\
\hline 232 & 293 & 184 & 186 & 139 & 99 & 131 & 120 & 755 & 712 & \\
\hline 233 & 304 & 180 & 181 & 152 & 104 & 140 & 130 & 844 & 778 & \\
\hline 234 & 309 & 181 & 181 & 140 & 94 & 144 & 122 & 773 & 796 & \\
\hline 235 & 311 & 177 & 176 & 139 & 101 & 134 & 121 & 785 & 757 & \\
\hline ? 236 & 312 & 175 & 174 & 135 & 103 & 126 & 118 & 771 & 720 & \\
\hline 237 & 300 & 180 & 183 & 147 & 103 & 141 & 123 & 817 & 783 & \\
\hline 238 & 299 & 182 & 184 & 141 & 99 & 137 & 122 & 775 & 753 & \\
\hline 239 & 314 & 174 & 175 & 146 & 94 & 130 & 123 & 839 & 747 & \\
\hline 240 & 315 & 173 & 172 & 141 & 96 & 132 & 120 & 815 & 763 & Asterion ossicle on right side. \\
\hline 241 & 316 & 167 & 171 & 144 & 101 & 131 & 117 & 862 & 784 & \\
\hline 242 & 319 & 179 & 183 & 153 & 105 & 137 & 126 & 855 & 765 & \\
\hline 243 & 324 & 183 & 181 & 147 & 104 & - & 130 & 803 & - & \\
\hline 244 & 331 & 177 & 178 & 142 & 101 & 145 & 127 & 802 & 819 & \\
\hline 245 & 334 & 182 & 181 & 140 & 102 & $12 \tilde{0}$ & 122 & 769 & 687 & \\
\hline 246 & 341 & 171 & 175 & 141 & 98 & 135 & 119 & 825 & 789 & Some reddish hair found on occiput. \\
\hline 247 & 349 & 180 & 182 & 141 & 98 & 125 & 112 & 783 & 694 & $\begin{array}{l}\text { Metopic suture open externally } \\
\text { and below internally. Asterion } \\
\text { ossicle on each side. }\end{array}$ \\
\hline 248 & $349 \mathrm{~A}$ & 176 & 181 & 145 & 99 & 138 & 122 & 824 & 784 & \\
\hline$? 249$ & 352 & 172 & 171 & 146 & $98 ?$ & 128 & 117 & 849 & 744 & \\
\hline 250 & 354 & 171 & 173 & 145 & 97 & 128 & 118 & 848 & 749 & \\
\hline 251 & 355 & 174 & 175 & 141 & 98 & 137 & 121 & 810 & 787 & \\
\hline 252 & 356 & 186 & 188 & 139 & 95 & 128 & 119 & 747 & 688 & Scaphocephalic. \\
\hline 253 & 357 & $17 \check{0}$ & 174 & 154 & 109 & 140 & 131 & 880 & 800 & \\
\hline 254 & 359 & 165 & 167 & 142 & 95 & 137 & 122 & 861 & 830 & \\
\hline 255 & 364 & 175 & 177 & 148 & 99 & 135 & 125 & 846 & 771 & \\
\hline 256 & 365 & 182 & 186 & 139 & 100 & 132 & 120 & 764 & 725 & \\
\hline 257 & 369 & 171 & 173 & 134 & 96 & 128 & 115 & 784 & 749 & Palatine torus. \\
\hline 258 & 373 & 179 & 182 & 150 & 89 & 138 & 125 & 838 & 771 & \\
\hline 259 & 375 & 193 & 195 & 145 & 97 & 128 & 119 & 751 & 663 & Bathrocephalic with wormian bones. \\
\hline 260 & 381 & 183 & 183 & 135 & 94 & 127 & 115 & 738 & 694 & \\
\hline 261 & 383 & 183 & & 146 & 101 & - & - & 798 & - & \\
\hline 262 & 385 & 175 & 178 & 152 & 104 & 138 & 123 & 869 & 789 & Bathrocephalic with wormian bones. \\
\hline 263 & $388 \Delta$ & 174 & 177 & 147 & 101 & 137 & 124 & 845 & 787 & \\
\hline 264 & 390 & 182 & 186 & 142 & 99 & 133 & 124 & 780 & 731 & $\begin{array}{l}\text { Slightly bathrocephalic. Diamond- } \\
\text { shaped lambdoid ossicle. }\end{array}$ \\
\hline 265 & 391 & 167 & 169 & 138 & 90 & 129 & 115 & 826 & 772 & Slightly bathrocephalic. \\
\hline 266 & 393 & 185 & 186 & 139 & 100 & 135 & 123 & 751 & 730 & $\begin{array}{l}\text { Scaphocephalic. Slightly bathro- } \\
\text { cephalic. }\end{array}$ \\
\hline 267 & 394 & 176 & 182 & 142 & 100 & 138 & 123 & 807 & 784 & \\
\hline 268 & 396 & 165 & 169 & 138 & 94 & 131 & 122 & 836 & 794 & Epipteric bone on each side. \\
\hline 269 & 399 & 184 & 188 & 146 & 106 & 133 & 124 & 793 & 723 & \\
\hline 270 & 401 & 176 & 179 & 152 & 95 & 132 & 123 & 864 & 750 & \\
\hline 271 & 407 & & & 146 & & 132 & & - & - & $\begin{array}{l}\text { Bathrocephalic with wormian } \\
\text { bones. Lambdoid ossicle. }\end{array}$ \\
\hline 272 & 410 & 182 & 182 & 143 & 105 & 141 & 120 & 786 & 775 & Asterion ossicle on each side. \\
\hline 273 & 411 & 167 & 170 & 144 & 104 & 136 & 119 & 862 & 814 & \\
\hline
\end{tabular}


MALES-oontinued.

\begin{tabular}{|c|c|c|c|c|c|c|c|c|c|c|}
\hline No. & 窇 & 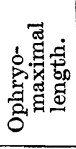 & 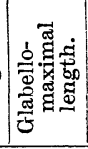 & 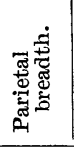 & 竞 & 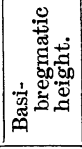 & 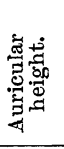 & 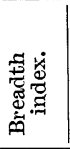 & 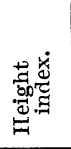 & \\
\hline 274 & 412 & 183 & 187 & 144 & 94 & 134 & 121 & 787 & 732 & Slightly bathrocephalic. \\
\hline 275 & 414 & 179 & - & 130 & 99 & 134 & 119 & 726 & 749 & \\
\hline 276 & 422 & 169 & 171 & 144 & 97 & 132 & 118 & 852 & 769 & \\
\hline 277 & 429 & 182 & 186 & 142 & 103 & 140 & 124 & 780 & 769 & \\
\hline 278 & 430 & 177 & 181 & 138 & 96 & 131 & 118 & 780 & 740 & Scaphocephalic. \\
\hline 279 & 431 & 171 & 171 & 146 & 106 & 131 & 120 & 854 & 766 & $\begin{array}{l}\text { Metopic suture partly open above } \\
\text { and below externally; closed } \\
\text { internally. }\end{array}$ \\
\hline 280 & 435 & 176 & 179 & 150 & 103 & 141 & 127 & 852 & 801 & Epipteric bone on right side. \\
\hline 281 & 436 & 180 & 179 & 142 & 96 & 131 & 123 & 789 & 728 & \\
\hline 282 & 438 & 178 & 180 & 145 & 97 & 128 & 119 & 815 & 719 & \\
\hline 283 & 440 & 175 & 180 & 153 & 105 & 136 & 129 & 874 & 777 & Scaphocephalic. \\
\hline 284 & 443 & 178 & 183 & 143 & 96 & 133 & 119 & 803 & 691 & \\
\hline 285 & 444 & 170 & 174 & 146 & 91 & 131 & 119 & 859 & 771 & \\
\hline 286 & 445 & 178 & 180 & 136 & 102 & 128 & 118 & 764 & 719 & \\
\hline 287 & 446 & 180 & 183 & 150 & $10 \tilde{5}$ & 136 & 119 & 833 & 756 & \\
\hline 288 & 447 & 170 & 171 & 136 & 102 & 129 & 116 & 800 & 759 & Scaphocephalic. Bregmatic ossicle. \\
\hline 289 & 448 & 170 & 171 & 141 & 98 & 135 & 122 & 829 & 794 & Scaphocephalic. \\
\hline 290 & 450 & 170 & 173 & 134 & 94 & 130 & 116 & 788 & 765 & Scaphocephalic. Lambdoid ossicle. \\
\hline 291 & 451 & 173 & 173 & 146 & 102 & 130 & 119 & 844 & 751 & Odontoid facet. \\
\hline 292 & 457 & 183 & 181 & 149 & 97 & 128 & 122 & 814 & 699 & Asterion ossicle on each side. \\
\hline 293 & 458 & 171 & 173 & 152 & 96 & 137 & 119 & 889 & 801 & \\
\hline 294 & 459 & 175 & 178 & 142 & 97 & 128 & 116 & 811 & 731 & \\
\hline 295 & 463 & 185 & 185 & 142 & 101 & - & 124 & 768 & - & Bathrocephaly with wormian bones. \\
\hline 296 & 469 & 186 & 188 & 135 & 94 & - & 121 & 726 & - & \\
\hline 297 & 473 & 180 & - & 142 & 104 & 126 & 115 & 789 & 700 & $\begin{array}{l}\text { Metopic suture partly open above } \\
\text { and below externally; closed } \\
\text { internally. }\end{array}$ \\
\hline 298 & 477 & 187 & - & 145 & 105 & 131 & 119 & 775 & 701 & \\
\hline 299 & 495 & 177 & 178 & 142 & 100 & 132 & 120 & 802 & 746 & \\
\hline 300 & 504 & 177 & 177 & 144 & 101 & - & - & 814 & - & \\
\hline 301 & 508 & 175 & 178 & 132 & 93 & 129 & 112 & 754 & 737 & Scaphocephalic. \\
\hline 302 & 514 & 172 & 173 & 142 & 94 & 126 & 117 & 826 & 733 & \\
\hline 303 & 515 & 183 & 186 & 147 & $94 ?$ & - & - & 803 & - & \\
\hline 304 & 529 & 165 & 169 & 135 & 92 & 120 & 107 & 818 & 727 & Scaphocephalic. \\
\hline 305 & 530 & 178 & 179 & 139 & 100 & - & - & 781 & - & Large healing wound on left parietal. \\
\hline 306 & 531 & 170 & 173 & 142 & - & - & - & 835 & - & $\begin{array}{l}\text { Symmetrical ossa triangularia in } \\
\text { occipital. }\end{array}$ \\
\hline 307 & 538 & 179 & 181 & 136 & 96 & 132 & - & 760 & 737 & $\begin{array}{l}\text { Trace of right interparictal suture } \\
\text { near asterion. }\end{array}$ \\
\hline 308 & 539 & 187 & 192 & 140 & 102 & 136 & 122 & 749 & 727 & \\
\hline 309 & 540 & 187 & 191 & 142 & 101 & 135 & 121 & 759 & 722 & Bathrocephalic with wormian bones. \\
\hline 310 & 541 & 186 & 188 & 141 & 104 & - & - & 758 & & \\
\hline 311 & 542 & 171 & 175 & 142 & 103 & 130 & 114 & 830 & 760 & \\
\hline 312 & 545 & 182 & 186 & 144 & 99 & 129 & 117 & 791 & 709 & \\
\hline 313 & 549 & 185 & 187 & 141 & 103 & 130 & 117 & 762 & 703 & \\
\hline 314 & 551 & 187 & $190 ?$ & 142 & 107 & - & 113 & 759 & - & \\
\hline 315 & 552 & 184 & 185 & 140 & 104 & 132 & - & 761 & 717 & \\
\hline ? 316 & 567 & 175 & 175 & 139 & 105 & 133 & 118 & 794 & 760 & \\
\hline 317 & 570 & - & - & 141 & 108 & 130 & 70 & - & $\vec{B}$ & \\
\hline 318 & 571 & 175 & 178 & 151 & 105 & 140 & 127 & 865 & 800 & \\
\hline $\begin{array}{l}319 \\
320\end{array}$ & $\begin{array}{l}572 \\
573\end{array}$ & $\begin{array}{l}174 \\
171\end{array}$ & $\begin{array}{l}177 \\
170\end{array}$ & $\begin{array}{l}140 \\
145\end{array}$ & $\begin{array}{r}102 \\
98\end{array}$ & $\begin{array}{l}123 \\
138\end{array}$ & 115 & $\begin{array}{l}805 \\
848\end{array}$ & $\begin{array}{l}707 \\
807\end{array}$ & Metopic. \\
\hline 321 & 577 & 167 & 168 & 142 & 100 & - & - & 850 & - & \\
\hline 322 & 582 & 172 & 174 & 146 & 99 & 133 & - & 849 & 773 & \\
\hline 323 & 583 & 177 & 176 & 139 & 94 & 125 & 117 & 785 & 706 & \\
\hline 324 & 585 & 174 & 174 & 136 & 104 & 134 & 119 & 782 & 770 & \\
\hline 325 & 587 & 174 & 174 & 154 & 104 & 140 & 127 & 885 & $80 \tilde{5}$ & \\
\hline 326 & 588 & 184 & 184 & 153 & 100 & 135 & 125 & 832 & 734 & \\
\hline
\end{tabular}


F. G. Parsons. - Report on the Hythe Crania.

FEMALES.

\begin{tabular}{|c|c|c|c|c|c|c|c|c|c|c|}
\hline No. & 离 & 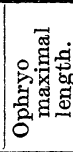 & 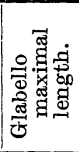 & 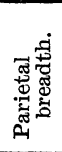 & 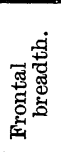 & 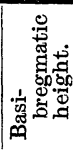 & 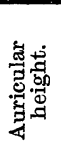 & 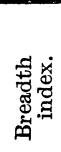 & 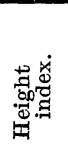 & \\
\hline 327 & 2 & 171 & 173 & 140 & 91 & 121 & 112 & 819 & 708 & \\
\hline 328 & 8 & 173 & 174 & 141 & 94 & 127 & 115 & 815 & 734 & Asterion ossicle ou each side. \\
\hline 329 & 11 & 163 & 164 & 137 & 95 & 123 & 115 & 840 & 755 & \\
\hline 330 & 20 & 172 & 172 & 150 & 97 & 132 & 120 & 872 & 767 & \\
\hline 331 & 21 & 172 & 173 & 134 & 96 & 124 & 111 & 779 & 721 & \\
\hline 332 & 24 & 162 & 163 & 145 & - & 122 & 114 & 895 & 753 & \\
\hline 333 & 26 & 170 & 169 & 137 & 94 & 123 & 116 & 806 & 724 & \\
\hline 334 & 33 & 170 & 170 & 140 & 96 & 132 & 120 & 824 & 776 & \\
\hline 335 & 52 & 174 & 174 & 136 & 93 & 124 & 119 & 782 & 713 & \\
\hline 336 & 73 & 174 & 174 & 144 & 98 & 131 & 120 & 828 & 753 & \\
\hline 337 & 65 & 171 & 172 & 140 & 98 & 117 & 112 & 819 & 684 & \\
\hline 338 & 74 & 179 & 177 & 139 & 106 & 125 & 113 & 777 & 698 & \\
\hline ? 339 & 25 & 181 & 184 & 151 & 105 & 137 & 125 & 834 & 757 & \\
\hline 340 & 107 & 162 & 163 & 136 & 94 & 120 & 107 & 840 & 741 & Epipteric bone on right side. \\
\hline 341 & 108 & 164 & 163 & 130 & 95 & 132 & 113 & 793 & 805 & Epipteric bone on right side. \\
\hline 342 & 129 & 167 & 171 & 144 & 96 & 126 & 111 & 862 & 754 & \\
\hline 343 & 135 & 164 & 165 & 137 & 95 & 125 & 112 & 835 & 762 & Epipteric bone on right side. \\
\hline 344 & 139 & 177 & 177 & 152 & 97 & 124 & 119 & 859 & 701 & \\
\hline 345 & 141 & 177 & 176 & 134 & 95 & 128 & 114 & 757 & 723 & \\
\hline 346 & 159 & 169 & 170 & 141 & 93 & 136 & 126 & 834 & 805 & \\
\hline ? 347 & 164 & 175 & 176 & 144 & 96 & 137 & 122 & 859 & 701 & \\
\hline 348 & 176 & 167 & 168 & 140 & 97 & - & - & 838 & - & \\
\hline ? 349 & 180 & 181 & 181 & 144 & 103 & 137 & 122 & 796 & 757 & \\
\hline ? 350 & 187 & 170 & 173 & 141 & 101 & 131 & 120 & 829 & 771 & \\
\hline 351 & 193 & 170 & 168 & 146 & 96 & 124 & 115 & 859 & 729 & \\
\hline 352 & 194 & 166 & 167 & 133 & 95 & 125 & 114 & 801 & 753 & \\
\hline ? 353 & 199 & 180 & 181 & 145 & 95 & 132 & 119 & 806 & 733 & \\
\hline 354 & 200 & 172 & 172 & 145 & 94 & 130 & 115 & 843 & 756 & \\
\hline 355 & 206 & 169 & 168 & 147 & 100 & 140 & 119 & 870 & 828 & \\
\hline 356 & 213 & 171 & 173 & 147 & 92 & 129 & 119 & 860 & 754 & \\
\hline ? 357 & 216 & 176 & 178 & 134 & 98 & 132 & 116 & 761 & 750 & \\
\hline ? 358 & 272 & 167 & 168 & 142 & 96 & 124 & 115 & 850 & 743 & \\
\hline 359 & 284 & 171 & 170 & 147 & 102 & 127 & 122 & 860 & 743 & \\
\hline 360 & 287 & 170 & 168 & 135 & 95 & 125 & 113 & 794 & 735 & \\
\hline ? 361 & 289 & 176 & 179 & 136 & 100 & 135 & 123 & 773 & 767 & Scaphocephalic. Bathrocephalic. \\
\hline$? 362$ & 291 & 173 & 173 & 149 & 109 & 132 & 120 & 861 & 763 & Asterion ossicle on right side. \\
\hline 363 & 302 & 182 & 182 & 142 & 90 & 129 & 114 & 780 & 709 & \\
\hline 364 & 303 & 169 & 170 & 147 & 101 & 130 & 119 & 870 & 769 & \\
\hline$? 365$ & 307 & 170 & 171 & 155 & 99 & 134 & - & 912 & 782 & \\
\hline 366 & 310 & 164 & 166 & 149 & 100 & 132 & 125 & 909 & 805 & \\
\hline 367 & 313 & 173 & 175 & 145 & 95 & 134 & 122 & 838 & 775 & \\
\hline ? 368 & 317 & 178 & 180 & 134 & 102 & 134 & 116 & 753 & 753 & \\
\hline$? 369$ & 318 & 159 & 160 & 138 & 92 & 128 & 115 & 868 & 792 & \\
\hline 370 & 327 & 159 & 162 & 139 & 93 & 130 & 114 & 874 & 818 & \\
\hline 371 & 335 & 180 & 180 & 141 & 95 & 127 & 114 & 783 & 706 & \\
\hline 372 & 337 & 176 & 176 & 147 & 103 & 129 & 114 & 835 & 733 & $\begin{array}{l}\text { Bathrocephalic with wormian } \\
\text { bones. }\end{array}$ \\
\hline 373 & 338 & 177 & 177 & 141 & 97 & 130 & 119 & 797 & 734 & \\
\hline 374 & 348 & 175 & 176 & 141 & 101 & 138 & 119 & 806 & 789 & \\
\hline 375 & 350 & 166 & 166 & 141 & 96 & 128 & 118 & 849 & 771 & \\
\hline 376 & 353 & 170 & 170 & 135 & 95 & 125 & 109 & 794 & 735 & \\
\hline 377 & 360 & 167 & 168 & 137 & 94 & 120 & 119 & 820 & 719 & $\begin{array}{l}\text { Anterior part of foramen magnum } \\
\text { deeply notched. }\end{array}$ \\
\hline ? 378 & 362 & 170 & 173 & 136 & 94 & 134 & 120 & 800 & 788 & Scaphocephalic. \\
\hline 379 & 374 & 170 & 171 & 138 & 96 & 134 & 113 & 812 & 788 & \\
\hline 380 & 382 & 171 & 172 & 137 & 100 & 127 & 114 & 801 & 743 & $\begin{array}{l}\text { Epipteric bone on each side. } \\
\text { Small facet for odontoid. }\end{array}$ \\
\hline 381 & 417 & 177 & 177 & 140 & 93 & 134 & 119 & 791 & 757 & \\
\hline
\end{tabular}

Vos. XXXVIII. 
FEMALES-continued.

\begin{tabular}{|c|c|c|c|c|c|c|c|c|c|c|}
\hline No. & 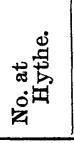 & 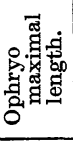 & 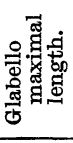 & 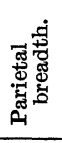 & 窇 & 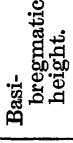 & 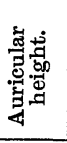 & 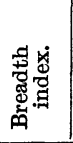 & 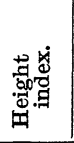 & \\
\hline ? 382 & 418 & 173 & 175 & 135 & 96 & 131 & 121 & 780 & 757 & Bilateral wormian ossicle. \\
\hline 383 & 424 & 170 & 171 & 141 & 92 & 135 & 121 & 829 & 794 & \\
\hline 384 & 434 & 162 & 161 & 142 & 92 & 123 & 119 & 877 & 759 & \\
\hline 385 & 220 & 180 & 180 & 134 & 94 & 128 & 115 & 744 & 711 & Perfect interparietal bone. \\
\hline 386 & 456 & 175 & 178 & 135 & 98 & 133 & 117 & 771 & 760 & \\
\hline 387 & 468 & 170 & 171 & 133 & 101 & 127 & 113 & 782 & 747 & \\
\hline 388 & 474 & 175 & 174 & 136 & 103 & 132 & 113 & 777 & 754 & \\
\hline 389 & 479 & 181 & 180 & 142 & 108 & 137 & 125 & 785 & 757 & \\
\hline 390 & 490 & 174 & 174 & 142 & 95 & 131 & 117 & 816 & 732 & \\
\hline 391 & 493 & 170 & 171 & 135 & 98 & 121 & 111 & 794 & - & \\
\hline 392 & 498 & 164 & 167 & 144 & 97 & 122 & 115 & 878 & 744 & Epipteric bone on right side. \\
\hline 393 & 509 & 172 & 172 & 142 & 98 & 135 & - & 826 & 785 & \\
\hline 394 & 519 & 174 & 175 & 145 & 94 & 126 & 120 & 833 & 724 & \\
\hline 395 & 524 & 178 & 178 & 142 & 95 & 130 & - & 798 & 730 & \\
\hline 396 & 526 & 161 & 164 & 146 & 101 & 130 & - & 907 & 807 & \\
\hline 397 & 527 & 171 & 171 & 145 & 95 & 135 & 123 & 848 & 789 & \\
\hline 398 & 528 & $170 ?$ & $168 ?$ & 138 & 94 & 120 & 113 & 812 & 706 & \\
\hline ? 399 & 532 & 175 & 177 & 141 & 97 & 123 & - & 806 & 703 & \\
\hline 400 & 537 & 169 & 168 & 143 & 97 & 125 & 119 & 846 & 740 & \\
\hline 401 & 550 & 170 & 173 & 141 & 97 & 123 & 114 & 829 & 724 & \\
\hline 402 & 564 & 164 & 165 & 142 & 90 & - & 115 & 866 & - & \\
\hline 403 & 566 & 173 & 173 & 138 & - & - & - & 798 & - & \\
\hline$? 404$ & 569 & 165 & 167 & 139 & 101 & 125 & 112 & 842 & 758 & \\
\hline 405 & 584 & 171 & 169 & 144 & 96 & 134 & 123 & 842 & 784 & \\
\hline 406 & 497 & 170 & 171 & 137 & 92 & 123 & 110 & 806 & 724 & \\
\hline 407 & 1 & 173 & 172 & 142 & 92 & 130 & - & 821 & 751 & \\
\hline 408 & 3 & 176 & 174 & 143 & 97 & 127 & - & 813 & 722 & \\
\hline 409 & 10 & 169 & 170 & 131 & 92 & 131 & 115 & 840 & 775 & \\
\hline 410 & 31 & 170 & 171 & 145 & 97 & 127 & 114 & 853 & 747 & \\
\hline 411 & 44 & 164 & 167 & 135 & 96 & 124 & 112 & 823 & 756 & Epipteric bone on right side. \\
\hline 412 & 47 & 170 & 171 & 139 & 102 & 129 & 114 & 818 & 759 & $\begin{array}{l}\text { Epipteric bone on right side. } \\
\text { Bathrocephalic without wormian }\end{array}$ \\
\hline 413 & 62 & 168 & 168 & 139 & 100 & 131 & 116 & 827 & 780 & Epipteric bone on right side. \\
\hline 414 & 64 & 178 & 178 & 141 & 96 & 121 & 113 & 792 & 680 & \\
\hline 415 & 68 & 168 & 169 & 139 & 96 & 129 & 117 & 827 & 768 & \\
\hline 416 & 71 & 164 & 163 & 135 & 96 & 122 & 112 & 823 & 744 & \\
\hline 417 & 79 & 169 & 169 & 142 & 99 & 117 & 114 & 840 & 692 & $\begin{array}{l}\text { Metopic suture open externally } \\
\text { and internally. Post coronal } \\
\text { depression. }\end{array}$ \\
\hline 418 & 85 & 171 & 172 & 139 & 93 & 126 & 108 & 813 & 737 & \\
\hline 419 & 87 & 174 & 174 & 133 & 92 & 123 & 112 & 764 & 707 & \\
\hline 420 & 92 & 174 & 174 & 142 & 99 & 130 & 122 & 816 & 747 & Metopic. Scaphocephalic. \\
\hline 421 & $100 \mathrm{~A}$ & 174 & 173 & 133 & 94 & 137 & 125 & 764 & 787 & Epipteric bone on each side. \\
\hline 422 & 110 & 172 & 171 & 144 & 97 & 131 & 116 & 837 & 762 & \\
\hline 423 & 117 & 169 & 168 & 133 & 92 & 130 & 117 & 787 & 769 & \\
\hline 424 & 119 & 171 & 172 & 143 & 97 & 130 & 117 & 836 & 760 & Scaphocephalic. \\
\hline 425 & 123 & 170 & 171 & 141 & 96 & 126 & 117 & 829 & 741 & $\begin{array}{l}\text { Slightly bathrocephalic with worm- } \\
\text { ian bones. }\end{array}$ \\
\hline 426 & 124 & 168 & 167 & 143 & 95 & 117 & 112 & 851 & 696 & Metopic. Epipteric bone on leftside. \\
\hline 427 & 126 & 169 & 168 & 136 & 97 & 127 & 113 & 805 & 751 & Asterion ossicle on each side. \\
\hline 428 & 130 & 172 & 172 & 148 & 95 & 131 & 115 & 860 & 762 & \\
\hline 429 & 131 & 170 & 170 & 141 & 93 & 131 & 119 & 829 & 771 & $\begin{array}{l}\text { Slightly bathrocephalic without } \\
\text { wormian bones. }\end{array}$ \\
\hline 430 & 136 & 175 & 175 & 130 & 94 & 133 & 118 & 743 & 760 & Scaphocephalic. Epipteric bone on \\
\hline 431 & 142 & 168 & 168 & 135 & 100 & 127 & 111 & 804 & 756 & \\
\hline 432 & 144 & 174 & 174 & 144 & 98 & 132 & 117 & 828 & 757 & \\
\hline 433 & 146 & 171 & 173 & 131 & 91 & 120 & 108 & 766 & 702 & Asterion ossicle on right. \\
\hline
\end{tabular}


FEMALES-continued.

\begin{tabular}{|c|c|c|c|c|c|c|c|c|c|c|}
\hline No. & 兽营 & 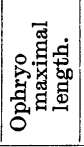 & 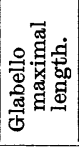 & 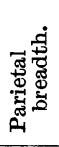 & 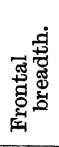 & 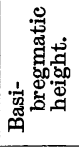 & 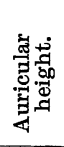 & 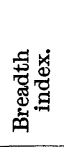 & 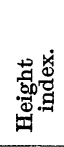 & \\
\hline 434 & 154 & 172 & 172 & 137 & 99 & 124 & 112 & 797 & 721 & $\begin{array}{l}\text { Epipteric bone on left side. Slightly } \\
\text { scaphocephalic. }\end{array}$ \\
\hline 435 & 157 & 166 & 167 & 132 & 102 & 118 & 110 & 795 & 711 & $\begin{array}{l}\text { Metopic. Bathrocephalic with } \\
\text { wormian bones. }\end{array}$ \\
\hline 436 & 162 & 165 & 167 & 141 & 90 & 121 & 112 & 855 & 733 & \\
\hline 437 & 167 & 166 & 165 & 139 & 93 & 127 & 116 & 837 & 765 & \\
\hline 438 & 170 & 166 & 165 & 138 & 96 & 131 & 117 & 831 & 789 & \\
\hline 439 & 181 & 166 & 165 & 136 & 93 & 125 & - & 819 & 753 & \\
\hline 440 & 184 & 172 & 174 & 144 & 99 & 127 & 118 & 837 & 738 & \\
\hline 441 & 186 & 170 & 170 & 133 & 91 & 124 & 117 & 782 & 729 & \\
\hline 442 & 191 & 167 & 167 & 140 & 99 & 135 & 116 & 838 & 808 & \\
\hline 443 & 198 & 174 & 175 & 148 & 100 & 130 & 121 & 851 & 747 & \\
\hline 444 & 205 & 179 & 178 & 140 & 93 & 127 & 114 & 782 & 709 & \\
\hline 445 & 208 & 187 & 189 & 142 & 102 & 136 & 123 & 759 & 727 & \\
\hline 446 & 211 & 158 & 156 & 134 & 90 & 126 & 115 & 848 & 797 & \\
\hline 447 & 212 & 170 & 169 & 140 & 90 & 126 & 114 & 824 & 741 & Epipteric bone on right side. \\
\hline 448 & 219 & 168 & 168 & 135 & 95 & 123 & 113 & 804 & 732 & \\
\hline 449 & 232 & $179 ?$ & $\overline{-10 x}$ & 147 & 97 & 134 & 120 & 821 & 749 & \\
\hline 450 & 235 & 161 & 161 & 130 & 98 & 125 & 110 & 807 & 776 & \\
\hline 451 & 255 & 174 & 172 & 142 & 100 & 130 & 116 & 816 & 747 & $\begin{array}{l}\text { Metopic suture open externally and } \\
\text { internally. }\end{array}$ \\
\hline 452 & 257 & 178 & 179 & 137 & 92 & 128 & 113 & 770 & 719 & \\
\hline 453 & 258 & 172 & 172 & 144 & 96 & 130 & 115 & 837 & 756 & Epipteric bone on left side. \\
\hline 454 & 262 & 170 & 169 & 134 & 92 & 132 & 118 & 788 & 776 & \\
\hline 455 & 278 & 167 & 167 & 142 & 93 & 130 & 118 & 850 & 778 & Epipteric bone on right side. \\
\hline 456 & 281 & 174 & 175 & 137 & 87 & 136 & 117 & 787 & 782 & Odontoid facet. \\
\hline 457 & 253 & 166 & 171 & 140 & 92 & 139 & 121 & 843 & 837 & $\begin{array}{l}\text { Plagiocephalic without obliteration } \\
\text { of sutures. Epipteric bone on } \\
\text { left side. }\end{array}$ \\
\hline 458 & 285 & 170 & 169 & 134 & 92 & 132 & 118 & 788 & 776 & Metopic. \\
\hline 459 & 286 & 188 & 185 & 138 & 98 & - & 118 & 734 & - & $\begin{array}{l}\text { Metopic. Slightly scaphocephalic } \\
\text { in frontal region. }\end{array}$ \\
\hline 460 & 265 & 171 & 172 & 146 & 98 & 134 & 122 & 854 & 784 & Epipteric bone on each side. \\
\hline 461 & 268 & 170 & 170 & 135 & 98 & 130 & 118 & 794 & 765 & $\begin{array}{l}\text { Metopic. Scaphocephalic. Small } \\
\text { lambdoid ossicle. }\end{array}$ \\
\hline 462 & 276 & 167 & 166 & 131 & 96 & 128 & 119 & 784 & 766 & $\begin{array}{l}\text { Epipteric bone on each side. As- } \\
\text { terion ossicle. }\end{array}$ \\
\hline 463 & 296 & 170 & 173 & 139 & 93 & 131 & 119 & 818 & 771 & \\
\hline ? 464 & 298 & 184 & 185 & 137 & 104 & 122 & 114 & 745 & 663 & $\begin{array}{l}\text { Metopic. Bathrocephalic. Aster- } \\
\text { ion ossicle on right side. Epip- } \\
\text { teric bone on each side. }\end{array}$ \\
\hline 465 & 306 & 167 & 168 & 137 & 98 & 125 & 112 & 820 & 749 & $\begin{array}{l}\text { Small bilateral lambdoid ossicles. } \\
\text { Asterion ossicle on right side. }\end{array}$ \\
\hline 466 & 322 & 177 & 178 & 133 & 90 & 130 & 111 & 751 & 734 & \\
\hline 467 & 326 & 164 & 164 & 144 & 97 & 128 & 117 & 878 & 780 & \\
\hline 468 & 330 & 163 & 163 & 145 & 90 & 123 & 112 & 890 & 755 & Large bregmatic ossicle. \\
\hline 469 & 323 & 165 & 166 & 146 & 96 & 126 & 121 & 885 & 764 & \\
\hline 470 & 325 & 164 & 164 & 144 & 96 & 134 & 118 & 878 & 817 & Asterion ossicle on each side. \\
\hline 471 & 332 & 183 & 184 & 130 & 97 & 124 & 113 & 710 & 678 & Scaphocephalic. \\
\hline 472 & 333 & $179 ?$ & $\overline{1-5}$ & 144 & 100 & - & 121 & 804 & - & \\
\hline$? 473$ & 366 & 174 & 175 & 139 & 99 & 119 & 108 & 799 & 684 & \\
\hline$? 474$ & 367 & 174 & 175 & 141 & 100 & 126 & 123 & 810 & 724 & \\
\hline 475 & 336 & 172 & 172 & 143 & 97 & 130 & 120 & 831 & 756 & Epipteric bone on right side. \\
\hline 476 & 339 & 171 & 172 & 138 & 93 & 130 & 114 & 807 & 760 & Metopic. \\
\hline 477 & 351 & 177 & 176 & 145 & 98 & 128 & 119 & 819 & 723 & \\
\hline 478 & 370 & 186 & 186 & 141 & 103 & 134 & 122 & 758 & 720 & Upper half metopic suture open. \\
\hline 479 & 371 & $173^{\circ}$ & 171 & 144 & 96 & 124 & 115 & 832 & 717 & \\
\hline 480 & 361 & 156 & 155 & 149 & 90 & 122 & 119 & 955 & 782 & \\
\hline
\end{tabular}


FEMALES-continued.

\begin{tabular}{|c|c|c|c|c|c|c|c|c|c|c|}
\hline No. & 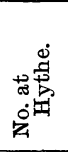 & 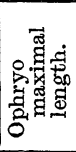 & 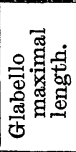 & 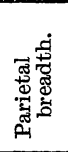 & 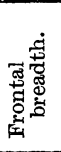 & 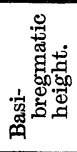 & 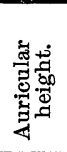 & 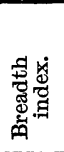 & 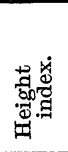 & \\
\hline 481 & 376 & 168 & 167 & 147 & 96 & 130 & 119 & 875 & 774 & Metopic. \\
\hline 482 & 377 & 167 & 169 & 140 & 93 & - & 121 & 838 & & \\
\hline ? 483 & 379 & 177 & 180 & 136 & 96 & 134 & 119 & 768 & 757 & Wormian bone in front of lambda \\
\hline 484 & 380 & 175 & 175 & 132 & 92 & 127 & 115 & 754 & 726 & \\
\hline ? 485 & 384 & 158 & 159 & 144 & 88 & 131 & 119 & 911 & 829 & $\begin{array}{l}\text { Plagiocephalic. Left half coronal } \\
\text { suture obliterated. }\end{array}$ \\
\hline 486 & 398 & 160 & 159 & 133 & 94 & 126 & 110 & 831 & 788 & \\
\hline 487 & 402 & 177 & 178 & 137 & 93 & 131 & 119 & 774 & 740 & \\
\hline 488 & 404 & 162 & 164 & 145 & 98 & 128 & 115 & 895 & 790 & Paroccipital process on left side. \\
\hline ? 489 & 408 & 166 & 168 & 138 & 97 & 123 & 114 & 831 & 741 & \\
\hline 490 & 403 & 163 & 163 & 141 & 94 & 128 & 122 & 865 & 785 & \\
\hline 491 & 409 & 161 & 159 & 142 & 100 & 127 & 115 & 882 & 789 & $\begin{array}{l}\text { Metopic suture closed internally in } \\
\text { lower half. } \\
\text { right side. }\end{array}$ \\
\hline 492 & 419 & 174 & 174 & 137 & 95 & 122 & 111 & 787 & 701 & \\
\hline 493 & 420 & 172 & 172 & 140 & 98 & 125 & 115 & 814 & 727 & \\
\hline $\begin{array}{r}494 \\
2495\end{array}$ & 321 & 170 & 171 & 145 & 100 & 140 & 126 & 853 & 824 & Fninteric hono on 1 \\
\hline ? 495 & 425 & 162 & 166 & 145 & 88 & 120 & 119 & 895 & 778 & $\begin{array}{l}\text { Epipteric bone on le } \\
\text { Bregmatic ossicle. }\end{array}$ \\
\hline $\begin{array}{l}496 \\
497\end{array}$ & $\begin{array}{l}428 \\
432\end{array}$ & 177 & 177 & 141 & 95 & 134 & 120 & $\begin{array}{l}797 \\
888\end{array}$ & $\begin{array}{l}757 \\
801\end{array}$ & \\
\hline 498 & 449 & 170 & 166 & 141 & 99 & 127 & 116 & $\begin{array}{l}888 \\
829\end{array}$ & $\begin{array}{l}801 \\
747\end{array}$ & Metopic. Postcoronal depression. \\
\hline 499 & 460 & 175 & 176 & 130 & 91 & 132 & 115 & 743 & 750 & \\
\hline$? 500$ & 465 & 171 & 170 & 137 & 100 & 129 & 117 & 801 & 754 & \\
\hline 501 & 466 & 177 & 179 & 134 & 99 & 128 & 115 & 757 & 723 & \\
\hline 502 & 467 & 171 & 170 & 138 & 100 & 124 & 114 & 807 & 725 & $\begin{array}{l}\text { Bathrocephalic with wormian } \\
\text { bones. Left half os pentagonale. }\end{array}$ \\
\hline$? 503$ & 462 & 172 & 174 & 140 & 92 & 119 & 110 & 814 & 692 & \\
\hline$? 504$ & 464 & 174 & 177 & 151 & 96 & 124 & 113 & 868 & 713 & \\
\hline 505 & 472 & 156 & 155 & 136 & 90 & 125 & 114 & 872 & 801 & $\begin{array}{l}\text { Plagiocephalic. Left half coronal } \\
\text { suture obliterated. }\end{array}$ \\
\hline 506 & 480 & 182 & 183 & 145 & 100 & 129 & 118 & 797 & 709 & Asterion ossicle on each side. \\
\hline $\begin{array}{l}507 \\
508\end{array}$ & 481 & 158 & 159 & 131 & 94 & 126 & 111 & 829 & 797 & \\
\hline $\begin{array}{l}508 \\
509\end{array}$ & $\begin{array}{l}482 \\
483\end{array}$ & $\begin{array}{l}170 \\
165\end{array}$ & $\begin{array}{l}170 \\
168\end{array}$ & $\begin{array}{l}136 \\
136\end{array}$ & $\begin{array}{l}96 \\
87\end{array}$ & $\begin{array}{l}120 \\
122\end{array}$ & $\begin{array}{l}109 \\
113\end{array}$ & $\begin{array}{l}800 \\
824\end{array}$ & $\begin{array}{l}706 \\
739\end{array}$ & epipteric bones on right \\
\hline 510 & 486 & 176 & 176 & 138 & 92 & 126 & 115 & 784 & 716 & $\begin{array}{l}\text { One epipteric bone on right side, } \\
\text { three on left side. }\end{array}$ \\
\hline 511 & 488 & 175 & 174 & 138 & 93 & 120 & 112 & 789 & 686 & \\
\hline 512 & 489 & 174 & 173 & 132 & 93 & 127 & 107 & 759 & 730 & \\
\hline 513 & 476 & 164 & 164 & 137 & 100 & 124 & 111 & 835 & 756 & Epipteric bone on right side. \\
\hline 514 & 494 & 164 & 161 & 137 & 95 & 127 & 114 & 835 & 774 & 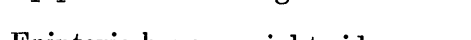 \\
\hline$? 515$ & 499 & 165 & 166 & 139 & 95 & 124 & 113 & 842 & 751 & Epipteric bone on right side. \\
\hline $\begin{array}{r}? 516 \\
517\end{array}$ & $\begin{array}{l}500 \\
501\end{array}$ & $\begin{array}{l}176 \\
168\end{array}$ & $\begin{array}{l}177 \\
168\end{array}$ & $\begin{array}{l}140 \\
141\end{array}$ & $\begin{array}{r}95 \\
103\end{array}$ & $\begin{array}{l}124 \\
113\end{array}$ & $\overline{108}$ & $\begin{array}{l}795 \\
839\end{array}$ & $\begin{array}{l}705 \\
672\end{array}$ & Odontoid facet. Post \\
\hline 518 & 001 & 168 & 168 & 141 & 103 & 113 & 108 & 839 & 672 & $\begin{array}{l}\text { Udontoid tacet. Post coronal } \\
\text { depression. }\end{array}$ \\
\hline $\begin{array}{l}518 \\
519\end{array}$ & $\begin{array}{l}502 \\
505\end{array}$ & $\begin{array}{l}168 \\
172\end{array}$ & $\begin{array}{l}168 \\
179\end{array}$ & $\begin{array}{l}133 \\
138\end{array}$ & $\begin{array}{l}92 \\
95\end{array}$ & 124 & 107 & 792 & 738 & \\
\hline 520 & 506 & 166 & 168 & 134 & 90 & $\begin{array}{l}130 \\
122\end{array}$ & 117 & 802 & $\begin{array}{l}756 \\
735\end{array}$ & Asterion ossicle on each side. \\
\hline 521 & 507 & 180 & 180 & 13 & 94 & 127 & 113 & 756 & 706 & \\
\hline 522 & 513 & 157 & 157 & 139 & 96 & 121 & 型 & 874 & 761 & \\
\hline $\begin{array}{l}523 \\
524\end{array}$ & $\begin{array}{l}516 \\
517\end{array}$ & $\begin{array}{l}159 \\
185\end{array}$ & $\begin{array}{l}161 \\
182\end{array}$ & $\begin{array}{l}138 \\
141\end{array}$ & $\begin{array}{r}94 \\
108\end{array}$ & 126 & 113 & 868 & 792 & ire open in lower \\
\hline 525 & 518 & 175 & 173 & 146 & 87 & 127 & - & 834 & 726 & Bathrocephaly with wormian \\
\hline ? 526 & 522 & 165 & 167 & 142 & 96 & 128 & 116 & 861 & 776 & \\
\hline 527 & 535 & 162 & 160 & 142 & 89 & 122 & 113 & 877 & 753 & Metopic. \\
\hline 528 & 543 & 168 & 169 & 136 & 90 & 129 & 111 & 810 & 768 & \\
\hline
\end{tabular}


FEMALES-continued.

\begin{tabular}{|c|c|c|c|c|c|c|c|c|c|c|}
\hline No. & 总密 & 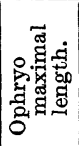 & 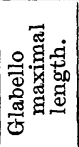 & 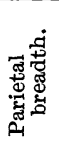 & 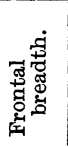 & 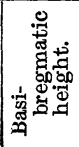 & 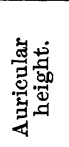 & 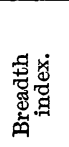 & 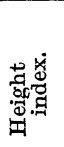 & \\
\hline$? 529$ & 546 & 170 & 171 & 138 & 92 & 121 & 110 & 812 & 712 & \\
\hline 530 & 547 & 161 & 161 & 140 & 92 & 120 & 114 & 870 & 745 & \\
\hline 531 & 553 & 180 & 186 & 135 & 91 & - & - & 750 & - & $\begin{array}{l}\text { Plagiocephalic. Left coronal su- } \\
\text { ture obliterated. }\end{array}$ \\
\hline 532 & 554 & 167 & 168 & 136 & - & - & - & 814 & - & \\
\hline 533 & 556 & 163 & 163 & 137 & 93 & 125 & 110 & 840 & 767 & \\
\hline 534 & 557 & 160 & 161 & 136 & 99 & 127 & 112 & 850 & 794 & \\
\hline 535 & 558 & 175 & 175 & 141 & 97 & 137 & 119 & 806 & 783 & \\
\hline 536 & 560 & 170 & 169 & 141 & 97 & 130 & 117 & 829 & 765 & Metopic. Scaphocephalic. \\
\hline 537 & 561 & 160 & 161 & 139 & 98 & 122 & 112 & 869 & 763 & \\
\hline 538 & 563 & 157 & 157 & 135 & 90 & 123 & 116 & 860 & 783 & Epipteric bone on each side. \\
\hline$? 539$ & 574 & 180 & - & 143 & 95 & 131 & 118 & 794 & 728 & $\begin{array}{l}\text { Bathrocephalic with wormian } \\
\text { bones. }\end{array}$ \\
\hline 540 & 579 & 167 & 166 & 142 & 98 & 133 & 120 & 850 & 796 & \\
\hline$? 541$ & 580 & 178 & 177 & 137 & 93 & 129 & 117 & 770 & 725 & $\begin{array}{l}\text { Occipito interparietal suture on } \\
\text { each side near asterion. }\end{array}$ \\
\hline 542 & 581 & 174 & 173 & 152 & 95 & 134 & 122 & 874 & 770 & \\
\hline$? 543$ & 586 & 178 & 178 & 138 & 97 & 135 & 118 & 775 & 758 & $\begin{array}{l}\text { Slightly bathrocephalic with } \\
\text { wormian bones. Epipteric bone } \\
\text { on right side. }\end{array}$ \\
\hline 544 & 590 & 177 & 177 & 134 & 93 & 129 & 117 & 757 & 729 & Bregmatic ossicle. \\
\hline 545 & 34 & 179 & 179 & 143 & 97 & 138 & 122 & 799 & 771 & \\
\hline$? 546$ & 54 & 184 & 184 & 153 & 104 & 127 & 120 & 832 & 690 & \\
\hline 547 & 80 & 167 & 170 & 141 & 97 & 137 & 120 & 844 & 820 & $\begin{array}{l}\text { Epipteric bone on right side. Os } \\
\text { triangulare on right side. }\end{array}$ \\
\hline 548 & 137 & 162 & 164 & 142 & 97 & 124 & 115 & 877 & 766 & $\begin{array}{l}\text { Epipteric bone on right side. } \\
\text { Bathrocephalic with wormian } \\
\text { bones. }\end{array}$ \\
\hline$? 549$ & 143 & 173 & 173 & 136 & 96 & 126 & 111 & 786 & 728 & Epipteric bone on right side. \\
\hline 550 & 169 & 179 & 180 & 135 & 100 & 124 & 117 & 755 & 693 & \\
\hline$? 551$ & 177 & 175 & 173 & 142 & 98 & 135 & 120 & 811 & 771 & \\
\hline 552 & 196 & 183 & 183 & 136 & 90 & 118 & 113 & 743 & 645 & \\
\hline 553 & 78 & 181 & 181 & 140 & 107 & 116 & 115 & 773 & 641 & Metopic. Post coronal depression. \\
\hline 554 & 88 & 172 & 173 & 140 & 98 & 127 & 114 & 814 & 738 & Epipteric bone on right side. \\
\hline 555 & $105 \mathrm{~A}$ & 173 & 172 & 147 & 99 & 123 & 117 & 850 & 711 & Epipteric bone on right side. \\
\hline 556 & 328 & 168 & 168 & 144 & 94 & 128 & 117 & 857 & 762 & Depression at obelion. \\
\hline
\end{tabular}


CHILDREN UNDER 20.

\begin{tabular}{|c|c|c|c|c|c|c|c|c|c|c|c|}
\hline No. & 密 & 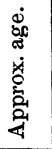 & 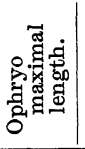 & 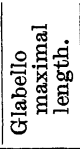 & 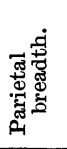 & 害苞 & 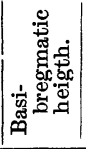 & 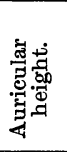 & 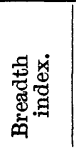 & 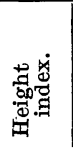 & \\
\hline 557 & 520 & 6 & 154 & 152 & 145 & 97 & 126 & 117 & 935 & 813 & \\
\hline 558 & 148 & 7 & 154 & 150 & 132 & 89 & 123 & - & 857 & 799 & $\begin{array}{l}\text { Four parts of occipital bone } \\
\text { separate. }\end{array}$ \\
\hline 559 & 149 & 7 & 169 & 162 & 136 & 98 & 123 & - & 805 & 728 & Metopic. Occipital complete. \\
\hline 560 & 470 & 7 & 157 & 156 & 134 & 98 & 126 & - & 854 & 803 & Metopic. Occipital complete. \\
\hline 561 & 267 & 7 & 165 ? & - & 138 & 90 & - & 116 & 836 ? & - & Occipital bone missing. \\
\hline 562 & 127 & 8 & 166 & 165 & 144 & 94 & 133 & 122 & 867 & 801 & \\
\hline 563 & 145 & 8 & 176 & 176 & 140 & 92 & $125 ?$ & 113 & 795 & $710 ?$ & $\begin{array}{l}\text { Basioccipital separate from } \\
\text { exoccipital. }\end{array}$ \\
\hline 564 & 523 & 8 & 163 & 161 & 135 & 88 & 125 & 114 & 828 & 767 & Occipital complete. \\
\hline 565 & 84 & 9 & 162 & 162 & 138 & 90 & 113 & 106 & 852 & 697 & Occipital complete. \\
\hline 566 & 156 & 9 & 154 & 148 & 137 & 94 & 113 & 107 & 890 & 779 & \\
\hline 567 & 151 & 9 & 165 & 164 & 143 & 86 & 125 ? & 119 & 867 & 758 & $\begin{array}{c}\text { Basioccipital separate from } \\
\text { exoccipital. }\end{array}$ \\
\hline 568 & 195 & 9 & $173 ?$ & - & 145 & 99 & - & 118 & 838 & - & Occipital bone missing. \\
\hline 569 & 492 & 9 & 173 & 173 & 135 & 96 & 125 & 114 & 780 & 723 & Metopic. \\
\hline 570 & 150 & 10 & 161 & 162 & 144 & 90 & 120 & $\overline{-1}$ & 894 & 745 & \\
\hline 571 & 153 & 10 & 158 & 157 & 141 & 98 & 123 & 118 & 892 & 778 & \\
\hline $572^{\circ}$ & 295 & 10 & 164 & 162 & 134 & 100 & 124 & 114 & 817 & 756 & Metopic. \\
\hline 573 & 343 & 11 & 166 & 165 & 138 & 99 & 125 & 115 & 831 & 753 & Metopic. \\
\hline 574 & 491 & 11 & 169 & 168 & 136 & 91 & 127 & - & 805 & 751 & \\
\hline 575 & 260 & 12 & 171 & 172 & 131 & 91 & 121 & 107 & 766 & 708 & Plagiocephalic. \\
\hline 576 & 533 & 12 & 168 & 165 & 134 & 96 & 119 & 111 & 798 & 708 & $\begin{array}{l}\text { Metopic suture open externally } \\
\text { in lower half. Epipteric } \\
\text { bone on each side. }\end{array}$ \\
\hline 577 & 290 & 12 & 150 & 149 & 129 & 86 & 122 & 110 & 860 & 813 & \\
\hline 578 & 282 & 12 & 173 & 173 & 147 & 96 & 125 & 113 & 850 & 723 & \\
\hline 579 & 152 & 14 & 160 & 160 & 134 & 92 & 126 & 110 & 838 & 788 & Metopic. \\
\hline 580 & 344 & 14 & 163 & 162 & 143 & 96 & 129 & 118 & 877 & 791 & ntagonale. \\
\hline 581 & 133 & 16 & 166 & 165 & 133 & 95 & 120 & 112 & 801 & 723 & Metopic. \\
\hline 582 & 378 & 17 & 167 & 167 & 150 & 97 & 127 & 120 & 898 & 760 & \\
\hline 583 & 89 & 18 & 179 & 180 & 138 & 90 & 132 & 115 & 771 & 737 & \\
\hline 584 & 116 & 18 & 161 & 162 & 135 & 88 & 120 & 106 & 839 & 745 & \\
\hline 585 & 118 & 18 & 176 & 175 & 139 & 98 & 130 & 117 & 790 & 739 & \\
\hline 586 & 511 & 18 & 173 & 173 & 140 & 83 & 129 & 112 & 809 & 746 & \\
\hline 587 & 512 & 18 & 172 & 171 & 141 & 96 & 123 & - & 820 & 715 & \\
\hline 588 & 534 & 18 & 179 & 181 & 141 & 91 & 127 & $\overline{11}$ & 788 & 709 & \\
\hline 589 & 536 & 18 & 161 & 164 & 150 & 91 & 124 & 115 & 932 & 770 & \\
\hline 590 & $115 \mathrm{~A}$ & 19 & 177 & 177 & 138 & 一 & 134 & 120 & 780 & 757 & \\
\hline
\end{tabular}


Journal of the Royal Anthropological Institute, Vol. XXXVIII, 1908, Plate XXXV.
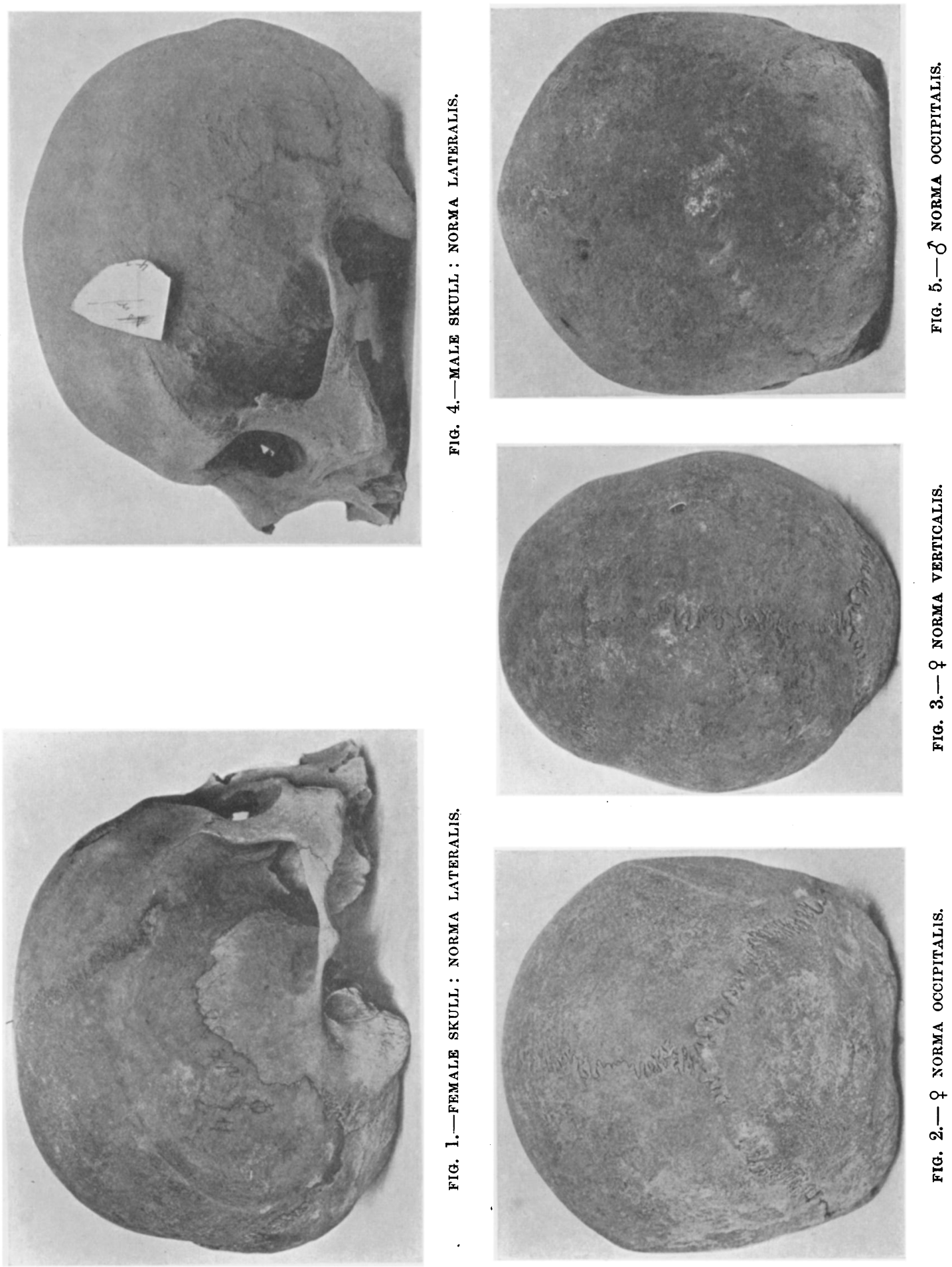

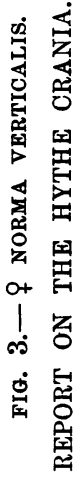

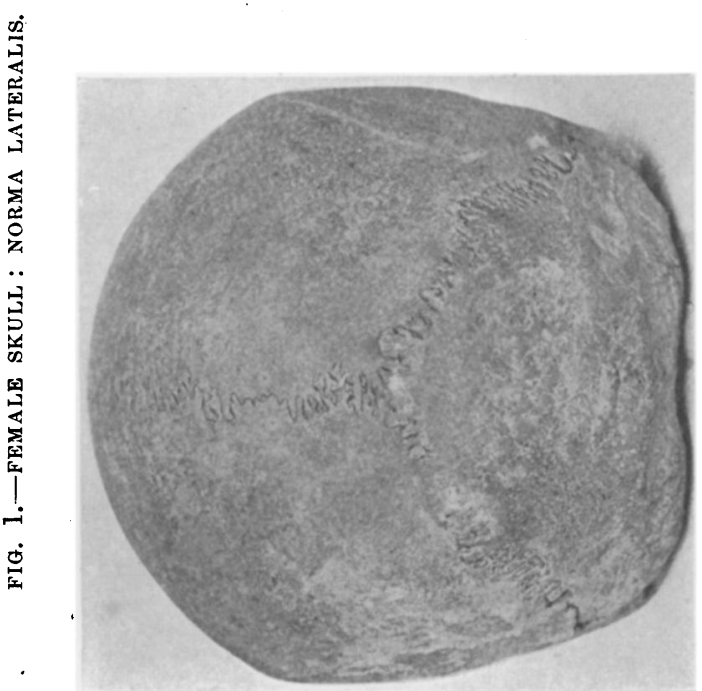

离 